\title{
Bilişsel edebi yaklaşım açısından resimli öykü kitaplarındaki duygu ifadelerinin incelenmesi ve 60-72 aylık çocuklara bu duyguların yansıması
}

\author{
Examining the emotional expressions in the picture story books according \\ to the cognitive literary approach and the reflection of these emotions in \\ childen 60-72 months old
}

\author{
Gülsüm Hoş $^{1}$, Ebru Deretarla Gül ${ }^{2}$
}

\author{
Makale Geçmişi \\ Geliş : 25 Aralık 2019 \\ Düzeltme : 13 .Mart 2020 \\ Kabul : 27 Haziran 2020

\section{Makale Türü} \\ Araştırma Makalesi
}

Öz: Araştırmanın birinci amacı, Bilişsel Edebi Yaklaşım çerçevesinde resimli öykü kitaplarındaki karakterlerin duygu ifadelerini, ikincisi ise bu duygu ifadelerinin 60-72 aylık çocuklardaki yansımasının incelenmesidir. Birinci çalışma grubu amaçlı örnekleme yöntemiyle seçilmiş 13 resimli öykü kitabından, ikinci çalıșma ise okul öncesi eğitim alan 10 çocuktan oluşmaktadır. Birinci çalıșmanın verileri doküman inceleme yöntemiyle toplanmış, içerik analizi yöntemiyle analiz edilmiştir. İkinci çalışmanın verileri yarı yapılandırılmış görüşme yöntemiyle toplanmış, içerik analizi yöntemiyle analiz edilmiştir. Birinci çalışmanın sonuçları altı kitabın resimlerinin öyküdeki karakterlerin zihinsel durumlarını fark etmeye ve anlamaya olanak sağladığını göstermiştir. İkinci araştırmanın bulguları, Bilişsel Edebi Yaklaşım açısından karakterlerin duygularını iyi yansıtan kitaplarda çocukların öykü karakterleriyle kolayca empati kurabildiğini göstermiştir.

Anahtar Kelimeler: Bilişsel edebi yaklaşım, Zihin okuma (Zihin Kuramı), Empati, Resimli öykü kitapları, Duygular, 60-72 aylık çocuklar

\begin{abstract}
The first aim of the study is to examine the emotion expressions of the characters in the picture story books in terms of Cognitive Literary Approach, and the second is to examine the reflections of these emotion expressions 60-72 months old children. The first study group consisted of 13 illustrated story books selected by purposive sampling method and the second study consisted of 10 preschool children. The data of the first study were collected by document analysis and analyzed by content analysis method. The data of the second study were collected by semi-structured interview and analyzed by content analysis method. Result of the first study showed that six picture story books allowed recognizing and understanding the mental states of the characters. Findings of the second study demonstrated that books that reflected the emotion of the characters well in terms of cognitive literary approach, children could empathize with the characters easily.
\end{abstract}

Keywords:Cognitive literary approach, Mind reading, empaty, Picture story book, Emotions, 60-72 months old children. 


\section{SUMMARY}

\section{Introduction}

Firstly meeting the book in the preschool period, a child tries to make sense of the fiction of the text in his/her memory by looking at the pictures. In order to make sense of this fiction, reading the pictures takes place prior to understanding the text. In this period, in which the child learns by seeing and hearing, picture story books play an important role. The right way to bring the unlimited benefits and contributions of the literary world to the child is through the use of content and illustration. In this study, the contribution of the books to the fictional world was explained. The aim of the study is to examine the emotional expressions and the reflections of these expressions in 60-72 month-old children with the interactions of pictures and texts in the picture story books in terms of Cognitive Literary Approach.

\section{Method}

In this study, qualitative research methods were used. The data of the first study were collected through the document analysis method and analyzed through the content analysis method. The data of the second study were collected through semi-structured interview method and analyzed through the content analysis method.

The sample of the first study consisted of 13 picture books for 3-6 year-old children written and/or illustrated by native or foreign authors or illustrators in Turkey. In the second study, the study group consisted of 10 children selected by using criterion sampling method among a total of 87 children aged 6072 months attending a special preschool education center in Tunceli.

As the data collection tool of the study, the "Book Imprint Form" and "Picture Book Checklist in terms of Cognitive Literary Approach", which was created by the researcher, were used. In the second study, the data were collected by means of "Gazi Early Childhood Development Assessment Tool" (GECDA), "Demographic Information Form", which was developed by the researcher, and "Two Picture Story Books".

In this study, initially, 13 picture story books were evaluated in terms of criteria in the book checklist. In the first part of the checklist, the data were collected through the "Physical Characteristics Expressing Emotion in Picture Story Books" and, "Content Characteristics in terms of Cognitive Literary Approach in Picture Story Books". In the second step of the study, the data were collected by semi-structured interview method. The data obtained through interviews were analyzed by the content analysis method. 


\section{Results}

13 picture story books were examined in the context of the first study and four themes were reached by content analysis. These were: (1) Expressions of Emotion in Pictures in Reflecting Mind Reading and Empathy (2) Expressions of Emotion in Texts in Reflecting Mind Reading and Empathy (3) Interaction of Picture and Text in Reflecting Expressions in Mind (4) Reflection Layers in Mind Reading. In the first theme it was seen that happiness (joy) (93) was the most used, fear (10) and confusion (10) were the least used emotions in the books. Additionally, it was found that the drawings causing the emotion of "uncertainty" were relatively high in the books (53). When all the books were examined according to the second theme, it was seen that "happiness" (63) and "sadness" (40) were processed intensively in the texts. In terms of reflecting emotional expressions, in the theme of picture and text interaction, it was seen that the cover titles of $\mathrm{K} 1, \mathrm{~K} 3, \mathrm{~K} 5, \mathrm{~K} 6, \mathrm{~K} 7, \mathrm{~K} 9, \mathrm{~K} 12$ and $\mathrm{K} 13$ were related to the character's emotion. Moreover, the cover pictures of K3, K12, K13 were also related to the character's emotion.

In the third theme; certain themes were evaluated such as "Cover picture is related to the emotional state of the character", "Cover title is related to the emotional state of the character", "Pictures describe the emotion described in the written text" and "Written text describes the emotion described in the pictures". When all the books were evaluated within the context of all criteria, it was found that there were 143 "yes" and 68 "no". In the fourth theme, it was seen that the second layer in mind reading (68 times) was used the most in the picture books. Furthermore, it was found that the reflective layer was still relatively high, being the third (59 times). The fourth (4 times) mind reading layer was also found in the sentences. Through the main purpose of the second study, two picture story books were used as the data collection tool. The data were analyzed through the content analysis method and two themes were reached. These were: (1) Reflection of Emotional Expressions in Pictures in Children by Mind Reading and Empathy, (2) Reflection of Emotional Expressions in Images in Children by Mind Reading and Empathy. In the first theme, children's expressions about their emotions were investigated through the external signs of the characters in the pictures. It was found out that the comments of the children for Book 1 were mostly unhappiness (64), followed by happiness (39) and finally surprise (1). In Book 2, it was revealed that children mostly talked about "happiness" (144), then "love" (17), "surprize" (7), "anger" (6) and finally "fear" (2). As per the second theme, the number of children using emotional expressions was low for the texts of the figures in Book 1 (Ş2, Ş5, Ş6, Ş12, Ş13, Ş14), but for the texts in the Book 2, it was seen that all children used emotional expressions. This pointed that Book 2 provided more opportunities for children to empathize and read minds than Book 1.

\section{Conclusion and Discussion}

The results of the study demonstrated that picture story books create opportunities for children for mind reading and empathizing for effective social interaction. It was seen that emotional expressions and understanding of these expressions through mind reading and empathy increase the interest of the child. It 
was found that picture story books can lead children to create new social statements. In addition, this study revealed that it is important to evaluate the emotions in picture story books in terms of conceptual basis of Cognitive Literary Approach. 


\section{GİRIŞ}

Sosyal etkileşim, kişiler arasındaki iletişimi anlayabilme, çeşitli sosyal durumlar arasındaki farkları algılama, empati kurabilme gibi boyutlarıyla, bireyin içinde yaşadığı toplumla uyumlu olması ve buna uygun sosyal davranışlar sergileyebilmesi için temel bir gerekliliktir (Ergenekon, 2012; Strayer, 1989). Sosyal etkileşimde insanlar, başkalarının düşünce, duygu ve inanç gibi zihinsel durumlarını göz önünde bulundurarak iletişimi şekillendirir, başkalarını anlar ve kendilerinin anlaşılırlığını da başkalarının zihinsel durumlarını göz önüne alarak değerlendirirler. Sözel olduğu kadar sözel olmayan etkileşimin anlaşılması, hareketlerin, yüz ifadelerinin yorumlanması, ortak bir amaç çerçevesinde işbirliği yapabilme, kendini bir başkasının yerine koyarak empati kurabilme (Gallagher ve Frith, 2003), anlatıların temasını kavrayabilme (Siegal ve Varley, 2002), farklı bakış açılarını yorumlama (Miller, 2006) gibi sosyal yaşamın önemli pek çok unsurunun başarılması bireyin kendisinin ve başkalarının zihinsel durumlarını değerlendirebilmesi becerisiyle ilişkili görülmektedir. Dolayısıyla çocuklar için zihinsel durumları anlama, davranış ve eylemleri zihinsel durumlara atıfta bulunarak yorumlama becerilerini ve empatiyi geliştirecek etkileşim firsatlarının yaratılması ve desteklerin sunulması son derece önem taşımaktadır (Fang, 1996).

Bu etkileşim fırsatlarının en önemlilerinden biri resimli öykü kitaplarıdır. Resimli öykü kitaplarının birincil özelliği görsel oluşudur. Dolayısıyla okuma yazmanın bilinmediği okul öncesi dönemde çocuğun gelişim sürecine katkı sağlayan kitaplarda resim kritik bir öğedir. Kitaplardaki resimler (görsel metinler) çocukların görsel algılarının gelişmesi için başlıca uyaranlardır. Çocuklara çizginin ve rengin anlatım olanaklarıyla yakın çevresi tanıtılır. Çocuklar kitaplardaki resimlere bakarak nesne ve varlıkların görsel niteliklerini tanır, onları adlandırmaya başlar. Ayrıca resimli öykü kitapları çocuklara yeni yaşantılar edinebilecekleri doğal öğrenme ortamları yaratır; resimleriyle, dilsel kurgularıyla, tasarımıyla çocuğun ilgisini çeker, çocukla yaşamı arasında bağ kurmasını sağlar ve onu eğlendirir (Sever, Dilidüzgün, Neydim ve Aslan, 2007).

Resimli öykü kitapları kişiliğin bir parçası olan duyguları, değer yargılarını ve anlayış tarzını şekillendirme konusunda oldukça önemli bir role sahiptir (Oğuzkan, 2013). Resimli öykü kitaplarının önemli rollerinden bir diğeri ise bireylerin zihin okuma becerisi ve empati gelişimlerine (Nikolajeva, 2012) katkı sunmasıdır. Resimli öykü kitaplarının değerlendirilmesinde yeni bir yaklaşım olan Bilişsel Edebi Yaklaşım, insan zihninin nasıl çalıştığını anlamaya çalışan biyolojik, psikolojik ve evrimsel araştırmaları kullanan insanların nasıl okuduğunu, yazdığını, paylaştığını, anlattı̆̆ını, karakterleri ne şekilde yorumladığını ve ilişkilendirdiğini, metaforları ne şekilde inşa ettiğini ve manipüle ettiğini açıklamaya çalışmaktadır (Bruhn, 2011; Crane, 2001; Gavins ve Steen, 2003; Stockwell, 2002). Yaklaşım, genel olarak kurgusal edebi çerçeve içinde ortaya çıkan mesajın 
okuyucu tarafindan hangi bilişsel süreçlerle anlaşıldığ1 ve okuyucunun kafasında nasıl bir resim ortaya çıkardığıyla ilgilenmektedir. Okul öncesi dönem çocuklarına indirgendiğinde ise yaklaşım; resim ve metin etkileşimiyle ortaya çıkan ve iletilmek istenen mesajın hangi duygu durumunu ortaya çıkardığını açıklamaya çalışmaktadır. Var olmayan kişisel problemleri, var olmayan düşünceleri ve duyguları ile asla var olmamış kurgusal insanlara ait kapsamlı bilginin, en yakınımızdaki veya uzağımızdaki insanları tanıma ve anlamamızla nasıl bir ilgisi olabileceği, kurgunun okuyuculara diğer insanların duygularını bilme ve anlama imkanı sunup sunamayacağı eğer sunabilirse bunun tam olarak nasıl olduğu, yaklaşımın temel konuları arasındadır (Nikolajeva, 2012).

Resimli öykü kitapları ile ilgili yurt içinde yapılan çalışmalarda kitapların daha çok niceliksel açıdan incelendiği ve imge şemalarına odaklanıldığı görülmüştür. Alper (2012), 2001-2010 y1lları arasında 3-6 yaş çocukları için Türkiye'de yayımlanmış resimli kitaplardaki karakterlerin, metin ve resimlemelerde hangi duygu durumlarına sahip oldukları incelemiştir. Araştırmanın sonucunda, metinde sözcük ve sözcük grubu olarak ifade edilen duygu durumlarından sevmek, sarılmak, mutlu olmak, sevinmek, kızmak, sinirlenmek, ağlamak, üzülmek, korkmak gibi okul öncesi dönemindeki çocukların anlayabileceği sözcüklerin yanı sıra, gurur duymak, bayılmak, koklaşmak, haykırmak, içi içine sığmamak, yerinde duramamak, şok geçirmek, gözlerine inanamamak, homurdanmak, içini çekmek, yakınmak, hayıflanmak, ürkmek gibi okul öncesi çocukların anlayamayacağı ifadelere de rastlanıldığı rapor edilmiştir.

Bilgin tarafından 2011 yılında yapılan araştırmada, 5-6 yaş çocuklarına yönelik resimli kitapların çocuğa görelik kavramına göre incelenmesinde kitaplar; kapak, resimleme, içerik, karakter, dil ve anlatım yönünden incelenmiştir. Araştırma bulguları çocuğa görelik kavramına göre nitelikli bir kitapta bulunması gerekenleri ve içinde çocuğa göreliği barındıran özellikleri ortaya koymuştur.

Akyol (2012), Türkiye'de okul öncesi çocuklarına yönelik Türkçe basılmış yerli ve yabancı resimli çocuk kitaplarında yer alan değerleri incelemiştir. Araştırmada veri toplama aracı olarak, araştırmacı tarafindan geliştirilen "Değerler Kontrol Listesi” kullanılmıştır. Araştırmadan elde edilen bulgular, çalışma grubunu oluşturan resimli çocuk kitaplarında en fazla kişisel ve kişiler arası değerlerin, en az ise toplumsal değerlerin yer aldığını göstermiştir.

Işıtan (2005), Türkiye'de Türkçe basılmış yerli ve yabancı resimli çocuk kitaplarının benlik kavramıyla ilgili mesajları içerip içermediklerini araştırmıştır. Araştırmanın örneklemini 1980-2003 yılları arasında basılmış olan, kütüphanelerde, özel koleksiyonlarda ve piyasada bulunan ve random yöntemiyle seçilmiş olan 45 çeviri, 195 yerli kitap olmak üzere toplam 250 kitap oluşturmuştur. Ayrıca, seçilen kitapların bir öykü özelliği taşımasına dikkat edilmiştir. Kitaplar, araştırmacı 
tarafından geliştirilen ve üç uzman görüşü alınarak hazırlanan "Benlik Kavramı Konuları Kontrol Listesi” ile değerlendirilmiştir. Araştırmada elde edilen bulgular sonucunda; örneklemi oluşturan resimli çocuk kitaplarının en fazla işlenen genel konusunun akran ve çevre ilişkileri olduğu, en az ise akademik durum ve fiziksel görünüm olduğu saptanmıştır.

Tokgöz (2006), ise yaptı̆̆ı çalışmada okul öncesi çocuklarına yönelik kitapların dil gelişimi ve anlambilimsel açıdan değerlendirilmesi konusunu araştırmıştır.

Yurt dışında yapılan çalışmalarda ise resimli öykü kitapları daha çok niteliksel açıdan incelenmiştir. Ganea (2008), küçük çocukların kurgu bilgisini resimli kitaplar ile gerçek dünya arasındaki ilişkiye ne ölçüde aktardıklarını araştırmıştır. Araştırma sonuçları, 15-18 aylık çocukların yeni öğrendikleri etiketleri hem resimden nesnelere, hem de nesnelerden resimlere aktarabildiğini ortaya çıkarmıştır. Ayrıca çocukların, gerçekçi fotoğraflar ve çizimlerle görselleştirilmiş nesneleri birbiriyle daha iyi ilişkilendirdiği görülmüştür. Erken yaşta başlayan ve gerçekçi çizimlere yakın resimli kitap etkileşimlerinin çocuğun, resimli kitaplar ile gerçek dünyayı daha iyi düzeyde ilişkilendirdiğini vurgulamıştır.

Sipe (1998), resimli kitaptaki kelimelerle resimler arasındaki ilişkinin kavramsallaştırıldığı çeşitli biçimlerde genel bir bakış açısı sağlamaya çalıştığı çalışmasında bu ilişkiyi tanımlamak için çeşitli kuramsal gelenek ve disiplinlerden yararlanmıştır. Araştırmacı, sözel ve görsel işaretleri ilişkilendirirken içsel olarak gerçekleşen şeyi daha kesin bir şekilde tanımlamak için, semiyotik “transmediation” kavramına dayanan bir metin-resim ilişkileri kuramı sunmuştur. Teoriyi daha açık hale getirmek için "Where the Wild Things Are?” başlıklı resimli öykü kitabını kullanmıştır.

Nikolajeva (2012), küçük yaştaki okurlara yönelik resimli kitaplarda metin ve resimlerin etkileşimi aracılı̆̆ıla duyguların nasıl iletildiğini araştırmıştır. Duygu tasviri kavramını duyguları temsil etmenin değişik yollarını göstermek için kullanılmıs ve zihin okuma, empati ve alıcının duyuşsal işleyişinin farklı yönlerine vurgu yapmıştır. Araştırmacı, resimli öykü kitaplarını analiz ederek resim ve metin etkileşimini açıklamaya çalışmıştır.

Resimli öykü kitaplarının çocukların empati gelişimine ve zihin okuma (diğerler insanları düşünsel anlama, sosyalleşme) becerisine katkısı olduğu hep iddia edilegelmiştir, fakat bunun tam olarak nasıl işe yaradığı bütün yönleriyle incelenmemiştir. Gerek çocuk gerek yetişkin edebiyatındaki kurgusal dünyanın zihin okuma becerisine ve empati gelişimine nasıl hizmet ettiği, var olmayan karakterlerin, problemlerin, düşüncelerin ve duyguların en yakınımızdaki veya uzağımızdaki insanları tanıma ve anlamamızla nasıl bir ilgisi ve ilişkisi olabileceği Bilişsel Edebi Yaklaşımın soruları arasındadır 
(Nikolajeva, 2012). Yurt içi literatürüne bakıldığında çocuk edebiyatı alanında, bilişsel bir yaklaşımın imkanlarının çok az ele alındığı görülmüştür. Çocukların kurgu ile ilgileri ve etkileşimleri üzerine yapılmış birçok nicel çalışma, çocukların edebi metinlerdeki duyguları anlayabilme yeteneği hakkında yeterince bilgi sunmamaktadır. Yapılan çalışmalarda resimli öykü kitapları çeşitli açılardan incelemiş olmakla birlikte küçük yaştaki okurların kurgu ile duygusal ilişkisi boyutuna değinilmemiştir. Ayrıca çalışmalarda Bilişsel Edebi Yaklaşımın çocuk edebiyatı kapsamında hiç ele alınmadığı da saptanmıştır. Bu durumda çocuk kurgusuna yaklaşımın teorik açıdan incelenmesi bir gereklilik olarak karşımıza çıkmaktadır. Resimli öykü kitaplarında metnin ve resmin uyandıracağı potansiyel duygu durumunun derinlemesine araştırılması gerekmektedir. Bu gereklilikten yola çıkan bu çalışmada, sözel ve görsel bileşenlerin birbirini desteklediği veya birbirinin aksi şeyler ifade edebildiği resimli öykü kitaplarının sosyal çevre içerisinde insanları anlama çabasına katkısı, resimli kitaplardaki resim ve metin etkileşimiyle duyguların nasıl aktarıldığı ve bu duyguların çocuklardaki yansıması araştırılmıştır. Bu kapsamda küçük yaştaki okurların kurgu ile duygusal ilişki konusuna odaklanan bu araştırmanın özgün bir çalışma olarak var olan literatüre katkı sunacağı ve bu konuda yapılacak başka çalışmalara yol göstereceği düşünülmektedir.

Yukarıdaki bilgiler ışığında bu araştırmanın genel amacı, Bilişsel Edebi Yaklaşım açısından resimli öykü kitaplarındaki duygu ifadeleri ve 60-72 aylık çocuklara bu duyguların yansıması incelenmiştir. Bu genel amaç doğrultusunda aşağıdaki alt amaçlar belirlenmiştir.

Resimli öykü kitaplarındaki duygu ifadelerinin incelenmesi çerçevesinde araştırmanın alt amaçları şunlardır:

- Resimler, öyküdeki karakter/karakterlerin zihinsel durumlarını fark ederek anlamaya (zihin okuma) ve karakterlerle empati kurmaya olanak sağliyor mu?

- Metin, öyküdeki karakter/karakterlerin zihinsel durumlarını fark ederek anlamaya (zihin okuma) ve karakterlerle empati kurmaya olanak sağlıyor mu?

- Resim ve metin etkileşimi duygu ifadelerini yansıtmaya olanak sağlıyor mu?

- Zihin okumada yansıtma katmanları metni anlamaya olanak sağlıyor mu?

Resimli öykü kitaplarındaki duygu ifadelerinin 60-72 aylık çocuklardaki yansımasının incelenmesi çerçevesinde araştırmanın alt amaçları şunlardır:

- 60-72 aylık çocuklar, karakter/lerin resim ve metin yoluyla aktarılan zihinsel durumlarını fark ederek anlayabiliyor mu?

- 60-72 aylık çocuklar, karakter/lerin resim ve metin yoluyla anlatılan duygu durumlarını öykü karakterleriyle empati kurarak anlayabiliyor mu? 


\section{YÖNTEM}

\section{Araştırma Modeli}

$\mathrm{Bu}$ araştırma birbiriyle ilişkili iki çalışmadan oluşmaktadır. Birinci çalışmanın temel amacı, Bilişsel Edebi Yaklaşım çerçevesinde resimli öykü kitaplarındaki metin ve resimler etkileşimiyle öykü karakterlerinin duygu durumlarının nasıl yansıtıldığını; ikinci çalışmanın temel amacı ise Bilişsel Edebi Yaklaşım açısından resimli öykü kitaplarındaki duygu ifadelerinin 60-72 aylık çocuklardaki yansımasını incelemektir. Araştırmanın amacı doğrultusunda nitel araştırma yöntemlerinden olan durum çalışması kullanılmıştır. Nitel durum çalışmasının en temel özelliği bir ya da birkaç durumun derinliğine araştırılmasıdır. Bu modelde mevcut durumlar, şartlar ve özellikler olduğu gibi ortaya konulmaya çalışılmaktadır (Yıldırım ve Şimşek, 2016). Bu bağlamda birinci çalışmada resimli öykü kitaplarındaki metinde geçen ve resimlerde görselleştirilen duygular, ikinci çalışmada ise 60-72 aylık çocukların resimli öykü kitaplarındaki duygu ifade eden metin ve resimlere yapmış olduğu yorumlar durum olarak ele alınmıştır. Araştırmanın birinci çalışmasında veriler doküman inceleme ve ikinci çalışmasında ise görüşme yöntemiyle toplanmıştır.

\section{Çalışma Grubu}

Birinci çalışmanın çalışma grubu, Türkiye'de yerli ve/veya yabancı yazar ve/veya resimleyene ait 36 yaş grubu çocuklar için en fazla yayıma sahip ilk on yayınevinin yayımladığı 613 resimli öykü kitabı arasından belirlenmiştir. Öncelikle, internet taraması yapılarak ve yaygın satış ağı olan kitapevlerinden bilgi alınarak okul öncesi döneme yönelik ve kurgusal metin olma özelliği içeren çocuk kitapları yayımlayan yayınevlerinin listesi oluşturulmuştur. Bu yayınevlerinin her birinin web adreslerinden, kataloglarından ve yaygın olarak kullanılan internet üzerinden kitap satışı yapan web sitelerinden, 3-6 yaş grubu çocuklarına yönelik yayımlanmış resimli kitap sayısı tespit edilmiş ve yayınevleri yayım sayılarına göre sıralanmıştır. En çok yayım yapan ilk on yayınevine ait 613 adet resimli kitap tespit edilmiştir. Duygu ifadelerinin yoğunlukta kullanıldığı kitapları belirlemek açısından amaçlı örnekleme yöntemi kullanılarak her bir yayınevinin yayınladığı kitapların \%2'si örneklemi temsil etmek üzere araştırmaya dahil edilmiştir. Toplamda 13 kitap araştırmanın çalışma grubunu oluşturmuştur.

Birinci çalışmanın çalışma grubunu, Türkiye'de yerli ve/veya yabancı yazar ve/veya resimleyene ait 3-6 yaş grubu çocuklar için en fazla yayıma sahip ilk on yayınevinin yayımladığı 613 resimli öykü kitabı arasından amaçlı örnekleme yöntemi kullanılarak belirlenmiş 13 resimli öykü kitabı oluşturmaktadır. İkinci çalışmanın çalışma grubunu ise Tunceli ili Merkezinde özel bir okul öncesi 
eğitim kurumuna devam eden 60-72 aylık toplam 87 çocuk içerisinden ölçüt örnekleme yöntemiyle seçilen 10 çocuk oluşturmaktadır. Ölçüt GEÇDA ile belirlenen benzer zihin, dil ve sosyal-duygusal gelişim düzeyine sahip olmayı gerektirmektir.

\section{Veri Toplama Araçları}

Birinci çalışmada veri toplama aracı olarak araştırmacı tarafından oluşturulan "Kitap Künye Formu” ve "Bilişsel Edebi Yaklaşım Açısından Resimli Kitap Kontrol Listesi” kullanılmıştır.

\section{Kitap künye formu}

Araştırmada kullanılan resimli öykü kitaplarına ait künye bilgilerinin belirlenmesi amacıyla "Kitap Künye Formu" kullanılmıştır. Kitap Künye Formu'nda; kitapların yazar, resimleyen, basım yılı, yayın evi, kitabın başlığı, sayfa sayısı, çeviri olup olmadığı hakkında bilgiler bulunmaktadır.

On üç resimli öykü kitabının sekizi çeviri, beşi yerli yayımdır. Çeviri kitapların beşinin yazar ve resimleyeni ayını kişiyken üçünün yazar ve resimleyeni farklı kişilerdir. Yerli kitapların ikisinin yazar ve resimleyeni aynı kişiyken üçünün yazar ve resimleyeni farklı kişilerdir. Tüm kitapların basım yılları genel olarak 2015 ile 2017 arasında, sayfa sayıları ise 30 ile 32 arasında değişmektedir.

\section{Bilişsel edebi yaklaşım açısından sesimli öykü kitap kontrol listesi}

Veri toplama araçlarından "Bilişsel Edebi Yaklaşım Açısından Resimli Öykü Kitap Kontrol Listesi”" oluşturulurken öncelikle alan yazındaki resimli çocuk kitaplarını incelemeye yönelik geliştirilmiş olan benzer veri toplama araçları incelenmiş ve literatür taraması yapılarak ne tür ve hangi içerikte veri toplama aracı geliştirileceğine araştırmacı tarafindan karar verilmiştir. Bu amaçla Nikolajeva'nın (2013) “Resimli Kitaplar ve Duygusal Okuryazalık" (Picturebooks and Emotional Literacy) adlı makalesinde belirtmiş olduğu dişsal işaretlerden (Dışal işaretler, resimleri okur kullandığımız ve gerçek hayatta zihin teorisini geçekleştirdiğimiz işaretlerdir) faydalanılmıştır.

Faydalanılan bir diğer kaynak ise Gönen, Aydos, Şentürk, Karacan, Kahraman ve Tuna (2013) tarafından "Resimli Çocuk Kitaplarının İçerik ve Fiziki Özelliklerinin İncelenmesi” başlıklı çalışmada geliştirilen kontrol listesidir. Araştırmacının faydalandığı bir diğer kaynak ise Demircan'ın (2006), “TUBİTAK Çocuk Kitaplığı Dizisindeki Kitapların Dış Yapısal ve İç Yapısal Olarak İncelenmesi” başlıklı çalışmasıdır. Ayrıca Gönen, Uludağ, Tanrıbuyurdu ve Tüfekçi’nin (2014), 0-3 yaş çocuklarına yönelik resimli çocuk kitaplarının özelliklerini incelemek amacıyla kullanmış oldukları "kitap kontrol listesinde" bulunan kritelerden de faydalanılmıştır. 
Hazırlanan veri toplama aracı, bir Okul Öncesi Eğitimi Alanı uzmanının, bir İletişim Çalışma Alanı uzmanının ve bir Türk Dili Alanı uzmanının görüşlerine sunulmuştur. Okul Öncesi Eğitimi Alanın uzmanı kontrol listesinde kullanılan ifadelerin içerik boyutunu inceleyerek araştırmanın kurumsal dayanakları ile resimli öykü kitap analizinin örtüşüp örtüşmediği konusunda dönütte bulunmuştur. İletişim Çalışmaları Alanı uzmanı, karakterlerin görsel temsili ve bu temsile eşlik eden sözel metinin analizinin uyguluğu yönünde görüş bildirmiştir. Türk Dili Alanı uzmanı ise kontrol listesini dil ve anlatım kontrolü yönünde incelemiştir. Son olarak onlardan gelen düzeltme önerilerine göre kontrol listesine son hali verilmiştir.

Araştırmada kullanılan ve araştırmacı tarafindan oluşturulan kitap kontrol listesi, 3-6 yaş grubu çocuklara yönelik okul öncesi dönem resimli kitapları duygu ifadelerini aktarma yönünden incelemektedir. Resimli kitaplar (dış kapakta dahil olmak üzere) Bilişsel Edebi Yaklaşım açısından değerlendirilmiş ve kontrol listesi duyguların yoğunlukta işlendiği kitabın her bir sayfası için değerlendirme aracı olarak kullanılmıştır.

İki bölümden oluşan kontrol listesinin birinci bölümünde "Resimli Öykü Kitaplarında Duygu İfade Eden Fiziksel Özellikler"e ilişkin 41, ikinci bölümünde ise "Resimli Öykü Kitaplarında Bilişsel Edebi Yaklaşım Açısından İçerik Özellikleri’ne ilişkin 16 madde yer almaktadır. Bu bölümler ve bölümlerdeki ölçütlerden bazıları şunlardır: Birinci bölüm olan "Resimli Öykü Kitaplarında Duygu İfade Eden Fiziksel Özellikler” ölçütü altında "Karakterlere (Ana/Yardımcı) ait Yüz İfadeleri”, "Karakterlere (Ana/Yardımcı) ait Beden Hareketleri” ve "Karakterin (Ana/Yardımcı) Mekansal Pozisyonları" bulunmaktadır. İkinci bölüm olan "Resimli Öykü Kitaplarında Bilişsel Edebi Yaklaşım Açısından İçerik Özellikleri” , "Resimli Öykü Kitabında Zihin Okumada Yansıtma Katmanları”, “ Resimli Öykü Kitabındaki Karakterlerin (Ana/Yardımcı) Duygu İfadeleri” ve “Duygu İfadesini Yansıtma Açısından Resim-Metin Etkileşimi” bulunmaktadır.

İkinci çalışmada veriler, "Gazi Erken Çocukluk Gelişimi Değerlendirme Aracı” (GEÇDA), araştırmacı tarafindan geliştirilen "Demografik Bilgi Formu” ve "İki Resimli Öykü Kitabı" aracılığıyla toplanmıştır.

\section{Gazi erken çocukluk gelişimi değerlendirme aracı (GEÇDA)}

Gazi Erken Çocukluk Gelişimi Değerlendirme Aracı (GEÇDA), Temel ve arkadaşları tarafından 2005 yılında 0-72 aylık çocuklarının gelişimlerini ayrıntılı olarak değerlendirerek gelişimsel geriliklerinin erken tanılanması amacıyla geliştirilmiştir. Araç, psikomotor gelişim, bilişsel gelişim, dil gelişimi ve sosyal-duygusal gelişim olmak üzere dört alt testten oluşmaktadır. GEÇDA, 73’ü 
psikomotor, 60'^ bilişsel, 60'1 dil ve 56'sı sosyal-duygusal gelişim alanına ait olmak üzere toplam 249 maddeden oluşmaktadır. Araç, uygun bir ortamda oluşturulan gelişimsel oyunlar esnasında çocuğun gözlenmesi ve gereken durumlarda çocuğu yakından tanıyan anne, baba veya bakıcısından bilgi alma yoluyla uygulanmaktadır (Temel, Ersoy, Avcı ve Turla, 2005). Araç, ikinci çalışmanın çalışma grubunda bulunan 10 çocuğun bilişsel, dil ve sosyal gelişim düzeylerini tespit etmek amacıyla kullanılmıştır. Yapılan değerlendirme sonucunda çocukların benzer gelişim özelliklerine sahip olduğu tespit edilmiştir.

\section{Demografik bilgi formu}

Çocuklara ait demografik bilgileri içeren bilgi formudur. Bu formda çocukların; cinsiyet, yaş (yıl ve ay), kardeş sayısı, okul öncesi kuruma devam etme süresi, anne babanın öğrenim durumu, anne babanın mesleği ve sosyo-ekonomik durumuna ilişkin bilgiler bulunmaktadır.

\section{Seçilen iki resimli öykü kitabı}

İkinci çalışmanın üçüncü veri toplama arac1 13 resimli öykü kitabı arasından araştırmacı tarafından seçilerek "Bilişsel Edebi Yaklaşım Açısından Resimli Öykü Kitap Analizi Kontrol Listesi" kullanılarak betimsel çözümlemesi yapılmış iki kitaptır. "Eyvah Kalbim Kırıldı!” (Kitap 1) başıklı öykü kitabı 32 sayfa olup yerli, “Tuhaf Bir Gün” (Kitap 2) başlıklı öykü kitabı ise 30 sayfa olup çeviri kitaptır. Kitapların her ikisinin de yazarı ve resimleyeni aynı kişidir. Birinci kitap 2016, ikinci kitap ise 2015 yılında basılmıştır.

Bu kitapların veri toplama aracı olarak seçilmesinde, Bilişsel Edebi Yaklaşım’ın kavramsal dayanakları olan "zihin okuma" ve "empatiyi” yansıtma durumu kriter olarak alınmıştır. Bu bağlamda “Kitap 1” bu kavramsal dayanakları iyi düzeyde yansıtmazken (belirsizlik içermesi) "Kitap 2" ise iyi düzeyde yansıtmaktadır.

\section{Verilerin Analizi}

Birinci çalışmanın çalışma gurubunu oluşturan 13 resimli öykü kitabı öncelikle kitap kontrol listesindeki özellikler ve kriterler yönünden değerlendirilmiştir. Kontrol listesi duyguların yoğunlukta işlendiği her bir sayfa için uygulanmıştır.

Kontrol listesinin ilk bölümünde "Resimli Öykü Kitaplarında Duygu İfade Eden Fiziksel Özellikler”e ve ikinci bölümünde ise "Resimli Öykü Kitaplarında Bilişsel Edebi Yaklaşım Açısından İçerik Özellikleri”"ne ilişkin veriler toplanmıştır. Veri toplam sürecinde "Bilişsel Edebi Yaklaşıma 
göre kitap kontrol listesi” bir başka araştırmacı tarafından seçilmiş olan 13 adet resimli kitaba uygulanmiştır.

Çalışmanın analizinde kullanılmak üzere araştırmacı tarafindan oluşturulan kontrol listesinden faydalanılarak resimli öykü kitaplarındaki duygu ifadeleri “Temel Duygular” kategorisi altında kodlanmış ve kodlanan duygu ifadelerinden temalara ulaşılmışır.

İkinci çalışmanın veri toplama sürecine, çalışmanın gerçekleşeceği okul yöneticilerine ve ailelerine araştırmanın içeriği hakkında bilgi verilerek ve gerekli izinler alınarak başlanmıştır. Uygulama yapılacak sınıflarda görev yapan okul öncesi öğretmenlerinden randevular alınmış ve buna göre araştırmacı yapacağı uygulamayla ilgili bir çalışma planı hazırlamışır. Çalışma, toplam 6 gün sürmüştür. Çocuklar 5'erli iki gruba ayrılmış ve tüm görüşmeler bire bir, ayrı bir sınıfta yapılmıştır. Araştırmacı çocuklara kitaplardaki karakterlerin duygu durumlarını tanımlaması ve tasvir etmesine yönelik sorular sormuş ardından öykü kitabını çocuklara okumuştur. Yapılan görüşmeler ses kayıt cihazıyla kaydedilmiş ve daha sonra kaydedilen bu görüşmeler incelenip düzenlenerek bilgiler bilgisayar ortamına aktarılmıştır. Ardından aktarılan bilgilerin içerik analizleri yapılmıştır. Çocukların vermiş olduğu cevaplardan yola çıkılarak temalar ve alt temalar oluşturulmuştur. Bulguların desteklenmesi hususunda çalışmada direk alıntılara yer verilmiştir. Çalışmaya katılan çocukların bilgileri gizli tutulacağından çocuklar Ç1, Ç2, Ç3,... şeklinde kodlanmıştır.

\section{BULGULAR}

Çalışmada elde edilen verilerin ve bulguların anlatıldığı ana bölümdür. Garamond yazı sitili 12 punto, 1.5 satır aralığı, paragraflarda girinti yapılmamalı, paragraflar öncesinde ve sonrasında otomatik boşluk bırakılmalıdır.Çalışmada elde edilen verilerin ve bulguların anlatıldığ1 ana bölümdür. Garamond yazı sitili 12 punto, 1.5 satır aralığı, paragraflarda girinti yapılmamalı, paragraflar öncesinde ve sonrasında otomatik boşluk bırakılmalıdır.

\section{Birinci Çalışmaya İlişkin Bulgular}

Araştırmanın amacı doğrultusunda 13 resimli öykü kitabı incelenmiş ve yapılan içerik analizi sonucunda dört temaya ulaşılmıştır. Bunlar: (1) Zihin Okuma ve Empatiyi Yansıtmada Resimlerdeki Duygu İfadeleri (2) Zihin Okuma ve Empatiyi Yansitmada Metinlerdeki Duygu İfadeleri (3) Duygu İfadelerini Yansıtmada Resim ve Metin Etkileşimi (4) Zihin Okumada Yansitma Katmanları'dır. 


\section{Zihin okuma ve empatiyi yansitmada resimlerdeki duygu ifadeleri}

Araştırmanın çalışma grubunu oluşturan 13 resimli kitaba ait resimlerdeki duygu ifadelerinin sayısal verileri Tablo 1'de gösterilmiştir. Kitaplar, “K1, K2, K3,K4, K5, K6, K7, K8, K9, K10, K11, K12 ve K13” şeklinde kodlanmıştır.

Tablo 1.13 resimli öykü kitabında resimlerdeki duygu ifadelerinin sayısı

\begin{tabular}{|c|c|c|c|c|c|c|c|c|c|c|c|c|c|c|}
\hline Duygular & K1 & $\mathrm{K} 2$ & K3 & K4 & K5 & K6 & $\mathrm{K} 7$ & K8 & K9 & $\mathrm{K} 10$ & K11 & K12 & K13 & $\overline{\text { Say1 }}$ \\
\hline $\begin{array}{l}\text { Mutluluk/ } \\
\text { Sevinç }\end{array}$ & 4 & 5 & 3 & 12 & 11 & 10 & 15 & 5 & 12 & 3 & 1 & 7 & 5 & 93 \\
\hline $\begin{array}{l}\text { Mutsuzluk/ } \\
\text { Üzüntü }\end{array}$ & & 6 & 4 & & & 3 & 1 & 2 & 3 & 1 & & 3 & 2 & 26 \\
\hline $\begin{array}{l}\text { Öfke/ } \\
\text { Kızgınlık }\end{array}$ & 10 & 3 & & 1 & & 1 & 2 & & & & & 2 & & 19 \\
\hline Korku & 3 & & & & & 2 & 1 & 1 & 1 & & & 2 & & 10 \\
\hline Sevgi/Aşk & 2 & 1 & & & & 5 & 12 & & & 1 & & 2 & & 23 \\
\hline Şaşkınlık & 1 & 1 & & & & 2 & 2 & & & 1 & 3 & & & 10 \\
\hline Belirsizlik & 2 & 1 & 5 & 2 & 6 & 3 & & 11 & 7 & 6 & 6 & 2 & 2 & 53 \\
\hline Toplam & 22 & 16 & 12 & 15 & 17 & 25 & 32 & 21 & 23 & 12 & 10 & 18 & 9 & \\
\hline
\end{tabular}

Tablo 1 incelendiğinde genel olarak tüm kitaplarda en fazla mutluluk (sevinç) duygusunun (93), en az korku (10) ve şaşkınlık (10) duygularının görselleştirildiği görülmektedir. Yine tüm kitaplar değerlendirildiğinde "belirsizlik" yaratan çizimlerin de nispeten fazla olduğu (53) saptanmıştır. Kitaplar tek tek incelendiğinde ise; K4, K5’te, K6, K9'da, K12 ve K13'de "mutluluk" (sevinç) duygusu, K2 ve K3'de “mutsuzluk” (üzüntü), K1'de “öfke” (k1zgınlık), K7’de ve K6'da “sevgi” (aşk), K5, K3, K8, K10 ve K11'de ise “belirsizlik” durumunun yoğunlukta olduğu görülmektedir. Aşağıda kitaplardaki duygu ifade eden görsel temsillere ilişkin örnekler sunulmuştur.

Kitap 1 ait Şekil 1'de yoğunlukta işlenen "kızgınlık" (öfke) duygusu ilk etapta dış kapakta görülmektedir. Resimli öykü kitabının kapağında kaşları çatık, ağzı ifade içermeyen düz bir çizgi ile görselleştirilmiş öykü kahramanı (kız çocuğu) ve kahramanın kendi boyutuna yakın büyüklükte kucakladığı bir hediye paketi resmedilmiştir. Karaktere ait bu dışsal işaretlerden (yüz ve ağız ifadesi) karakterin öfkeli ve kızgın olduğu anlaşılmaktadır. Karakterin zihnini okuma noktasında ise hediye paketine sahip olmak ve aynı zamanda kızgın olma duygusu bir ironi içermektedir. Mutlu olma sebeplerinden biri olan "bir hediyeye sahip olma" durumunun, kahramanda kızgınlığa sebep olmas1 bir duygusal karmaşa yaratmaktadır. Çünkü günlük hayatta zihinde hediye alma veya bir başkasına hediye verme temsili, mutlulukla özdeşleşmiştir. Küçük okurların da kendilerine verilen hediyeden mutlu oldukları ve dolayısıyla hediyeye sahip başka birinin de mutlu olacağına dair inançları vardır. Fakat kapak resminde karakterin sahip olduğu hediyeyi kucaklarken aynı zamanda kızgın oluşu 
küçük okurların karakterin zihnini okumada karmaşa yaşayacağını düşündürmektedir. Bunun yanı sıra kahramanın zihni farklı şekilde de okunabilir. Kız çocuğun kucakladığı hediye paketini paylaşmak istememesi veya bir başkasının hediye paketini kahramanın elinden alabileceğini düşünmesi şeklinde de yorumlanabilir. Dolayısıyla bu kayg1 durumunun da kızgınlığa yol açabilecektir. Bu ikinci varsayımda küçük okuyucudan sosyal bir duygu olan "paylaşma" duygusundan temel bir duygu olan "kızgınlık" duygusunun çıkarımı beklenmektedir. Buradaki bu duygusal zihin okuma çıkarımı 60-72 aylık çocuklar için karmaşık olmaktadır.

Kitap 5 ait Şekil 4’te ise bir taşın üstüne oturtmuş şekilde bir erkek çocuk resmedilmiştir. Çocuğun bir elini kaldırmış karşıya bakarken nasıl bir duygu durumu içinde olduğunu anlamak güçtür. Çocuğun ağız şekli ve bakışları duygu durumuna ilişkin net bir çıkarım yapmayı engellemektedir. Küçük okurların da karakterin dışsal işaretlerinden açı bir sonuca varmaları güçtür çünkü karakterin ifadesi belirsizlik taşımaktadır. Bu bağlamda çocukların karakterin zihnini okuması ve karakterle empati kurması belirsizlik içermektedir.

Kitap 6 ait Şekil 5’te iki zürafa ayakta ve biri diğerine çiçek koklatırken resmedilmiştir. Zürafaların birbirlerine yakın mesafede durmasından ve dışsal işaretlerinden (ağızlarının almış olduğu şekil) mutlu oldukları anlaşılmaktadır. Ayrıca birinin, diğerine koklaması için çiçeği burnuna yaklaştırması aralarında sevgiye dayalı bir etkileşim olduğunu göstermektedir. 66 aylık küçük okurların bu görselden zürafaların mutlu hissettikleri ve birbirlerini sevdiklerini ifade etmeleri beklenmektedir. Onların günlük deneyimleri arasında kadın ve erkek arasındaki sevgi ye aşka dayalı ilişkide çiçeğin bir sevgi sunumu aracı olduğu bilgisinin mevcut olduğu düşünülmektedir. Dolayısıyla çocukların öyküdeki kahramanların zihinlerini okuyarak onların mutlu hissettikleri ve birbirlerine karşı sevgi beslediklerini düşündükleri çıkarımına ulaşılabilir.

\section{Zihin okuma ve empatiyi yansitmada metinlerdeki duygu ifadeleri}

Resimli öykü kitaplarındaki metinlerde geçen duygu ifadelerinin sayısal değerleri Tablo 2'de verilmiştir. Duygular, temel duygu ifadeleri (kızdı, mutlu oldu, şaşırdım, korktum, vb.) ve dolaylı veya soyut olarak temel duygulara gönderme yapan ifadeler (kalbim kırıldı, gözler fal taşı gibi açıldı, ödü patladı, bayılırım, vb.) şeklinde tespit edilerek sayılmıştır.

Tablo 2. 13 resimli öykü kitabında metinde duygu ifade eden sözcük veya sözcük gruplarının sayısı

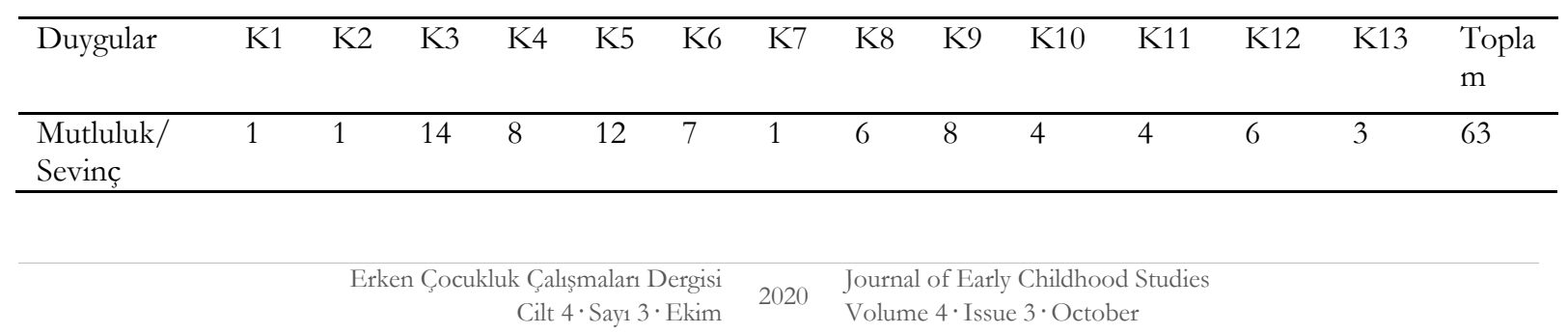




\begin{tabular}{|c|c|c|c|c|c|c|c|c|c|c|c|c|c|c|}
\hline $\begin{array}{l}\text { Mutsuzluk } \\
\text { /Üzüntü }\end{array}$ & & 5 & 11 & & 6 & 5 & 2 & 6 & & 2 & 2 & 2 & 2 & 40 \\
\hline $\begin{array}{l}\text { Öfke/ } \\
\text { Kizginlık }\end{array}$ & 2 & & & 2 & & & & 2 & & & & 3 & 3 & 15 \\
\hline Korku & & & & & & & & & & 4 & & 2 & & 6 \\
\hline Sevgi/Aşk & & & & & & 2 & 1 & & & & & & 1 & 4 \\
\hline Şaşkınlık & & 1 & & & & 2 & & 1 & 1 & & & & & 5 \\
\hline Belirsizlik & & & & & & & & & & & & & & 0 \\
\hline Toplam & 3 & 7 & 25 & 10 & 18 & 16 & 4 & 13 & 9 & 10 & 6 & 13 & 9 & \\
\hline
\end{tabular}

Tablo 2 incelendiğinde tüm kitaplardaki metinlerde "mutluluk" (63) ve “üzüntü” (40) duygularının yoğunlukta işlendiği görülmektedir. K2 ve K8'de “mutsuzluk” duygusu, K3, K4, K5, K6 ve K9'da "sevinç" duygusuna ait metinlerin yoğunlukta olduğu göze çarpmaktadır. Ayrıca K3 ve K8'deki “mutluluk" ve "üzüntü" duygularının yazılı ifadelerinin nicelik olarak birbirine yakın olduğu anlaşılmaktadır. Ayrıca K7, K11, K12'de, K10’da ve K13'te “üzüntü/mutsuzluk” duygusunun eşit sayıda yer aldığı dikkat çekmektedir. Diğer temel duygular olan “öfkenin”, "korkunun”, "sevginin” ve "şaşkınlığın" ise metinde daha az ifade edildiği görülmektedir. K7'de "mutluluk" duygusunun bir, "üzüntü” duygusun iki ve "sevgi” duygusunun bir kez ifade edildiği, K1'de ise "mutluluk" duygusun bir, "öfke” duygusunun ise iki kez ifade edildiği ve duygu ifadelerinin en az bu iki kitapta bulunduğu tespit edilmiştir. Kitaplardaki duygu ifade eden metinlere ilişkin örnekler aşağıda sunulmuştur.

Kitap 6 ait Şekil 7'de metin, "Börti ve Mavi bir anda kendilerini zebraların arasında buldular. Onlar da neşe içinde, zebralarla birlikte koşmaya başladılar. Börti kendini hiç bu kadar özgür ve mutlu hissetmemişti." şeklindedir. Metinde "özgür” ve “mutlu” hissetme aynı cümle içinde kullanılmıştır. Zürafaların, zebralarla birlikte koşmaları kendilerini özgür hissetmelerini ve buna bağlı olarak mutlu olmalarını sağlamıştır. "Özgürlük” koşma eylemiyle somutlaştırılmış "mutluluk" ise bunun sonucunda ortaya çıkarak yine somutlaştırılmıştır. 66 aylık çocukların zürafaların koşma eyleminden neden mutlu olduklarını, onların zihinlerini okuyarak ve empati kurarak anlayabilecekleri düşünülmektedir. Çocukların da oyun oynarken koşmaları ve diledikleri gibi özgürce davranmalarına ilişkin anılarını kolaylıkla zihinlerinden çağırmalarını sağlayacağı ve bundan dolayı öykü kahramanların mutluluklarını hissedebileceği öngörülmektedir.

Kitap 8 ait Şekil 8'deki “Porsuk öfkeyle haykırdı: 'Oy! Ne bakıyorsun gözetler gibi?’ O da çok huysuz bir porsuktu, üstelik o gün çok sinirliydil!" şeklindeki metinde "öfkeyle” ve "sinirliydi" ifadeleri temel duygulardan "öfke-kızgınlı̆̆a" işaret etmektedir. Metindeki bu duygu ifadesinde "Porsuğun" net bir öfke durumu içinde olduğu açıktır ve küçük okurların da bu ifadeden “porsuğun” kızgınlığını kolaylıkla anlayabileceği düşünülmektedir. 
Kitap 11'de Şekil 7'ye ait metin; “Aynaya baktığında bıyığını kesmediğini fark ediyor. Nasıl da üzülüyor! İyi de Şarkı Söyleyen Berber'e böyle gidemez ya!" şeklindedir. "Nasıl da üzülüyor!" ifadesi, berberin bıyığı olduğu için mi yoksa bıyığını kesmek zorunda kaldığı için mi üzgün olduğunu tam olarak açıklamamaktadır. İfadedeki bu belirsizliğin, 66 aylık çocukların karakterin zihnini okurken ve onun duygusunu hissederken bir belirsizlik yaşayabileceğini göstermektedir.

\section{Duygu ifadelerini yansıtmada resim ve metin etkileşimi}

13 resimli öykü kitabındaki duygu ifadelerini yansıtması açısından resim ve metin etkileşimini gösteren bilgiler Tablo 3'te yer almaktadır. Tabloda, kitaplarda temel duyguların geçtiği metinlere ve duyguların resimle örtüşme durumuna bakılmıs, E", "Evet"; "H" ise "Hayır" anlamında kullanılmıştır. Birincil duyguların metinlerde birebir yazılmadığı durumlarda bu duyguları ima eden ifadeler değerlendirmeye alınmıştır. Bu şekilde resim ve metin arasında etkileşimin olup olmadığ1 belirlenmiş ve buna göre sayısal veriler gösterilmiştir. Burada, "Kapak resmi, karakterin duygu durumuyla ilişkilidir.”, "Kapak başlı̆̆ı, karakterin duygu durumuyla ilişkilidir.”, "Resimler, yazılı metinde anlatılan duyguyu açıklar niteliktedir." ve "Yazılı metin, resimlerde anlatılan duyguyu açıklar niteliktedir.” ifadeleri kapsamında kitaplar değerlendirilmiştir.

Tablo 3. 13 resimli öykü kitabında duygu ifadelerini yansıtmada resim ve metin etkileşimi

\begin{tabular}{|c|c|c|c|}
\hline $\begin{array}{lr}\text { Duygu } & \text { Ífadesini } \\
\text { Yansıtması } & \text { Açısından } \\
\text { Resim-Metin Etkileșimi }\end{array}$ & Evet & Hayır & Toplam \\
\hline $\begin{array}{ll}\text { Kapak resmi, } & \text { karakterin } \\
\text { duygu } & \text { durumuyla } \\
\text { ilişkilidir. } & \\
\end{array}$ & $\begin{array}{l}\text { K1, K3, K5, K6, K7, K9, } \\
\text { K12, K13 }\end{array}$ & $\mathrm{K} 2, \mathrm{~K} 4, \mathrm{~K} 8, \mathrm{~K} 10, \mathrm{~K} 11$ & $\begin{array}{l}8 \mathrm{E} \\
5 \mathrm{H}\end{array}$ \\
\hline $\begin{array}{ll}\text { Kapak başlığı, karakterin } \\
\text { duygu } & \text { durumuyla } \\
\text { ilişkilidir. } & \\
\end{array}$ & $\mathrm{K} 3, \mathrm{~K} 12, \mathrm{~K} 13$ & $\begin{array}{l}\text { K1, K2, K4, K5, K6, K7, } \\
\text { K6, K9, K10, K11 }\end{array}$ & $\begin{array}{l}3 \mathrm{E} \\
10 \mathrm{H}\end{array}$ \\
\hline $\begin{array}{l}\text { Resim, } \\
\text { anlatilmak } \\
\text { duyguyu } \\
\text { niteliktedir. }\end{array}$ & $\begin{array}{l}\text { K1(4E), K2(3E), K4 } \\
(4 \mathrm{E}), \quad \text { K5(4E), K6(8E), } \\
\text { K7(2E), K8(6E), K9(5E), } \\
\text { K10(8E), K11(1E), } \\
\text { K12(10E), K13(8E) }\end{array}$ & $\begin{array}{lr}\mathrm{K} 2(1 \mathrm{H}), & \mathrm{K} 3(4 \mathrm{H}), \\
\mathrm{K} 5(4 \mathrm{H}), & \mathrm{K} 6(1 \mathrm{H}), \\
\mathrm{K} 8(3 \mathrm{H}), & \mathrm{K} 9(3 \mathrm{H}), \\
\mathrm{K} 10(4 \mathrm{H}), & \mathrm{K} 11(3 \mathrm{H}), \\
\mathrm{K} 12(1 \mathrm{H}), \mathrm{K} 13(2 \mathrm{H})\end{array}$ & $\begin{array}{l}67 \mathrm{E} \\
23 \mathrm{H}\end{array}$ \\
\hline $\begin{array}{l}\text { Metin, } \\
\text { anlatılmak } \\
\text { duyguyu } \\
\text { niteliktedir. }\end{array}$ & $\begin{array}{l}\text { K1(4E), K2(2E), K3(6E), } \\
\text { K4(4E), K5(4E), K6(8E), } \\
\text { K7(2E), K8(6E), K9(5E), } \\
\text { K10(7E), K11(1E), } \\
\text { K12(11E), K13(6E) }\end{array}$ & $\begin{array}{lr}\text { K2 }(1 \mathrm{H}), & \text { K3 }(1 \mathrm{H}), \\
\text { K5 }(4 \mathrm{H}), & \text { K6 }(1 \mathrm{H}), \\
\text { K8 }(3 \mathrm{H}), & \text { K9 }(3 \mathrm{H}), \\
\text { K10 }(5 \mathrm{H}), & \text { K11 }(3 \mathrm{H}), \\
\text { K12(3H) } & \\
\end{array}$ & $\begin{array}{l}67 \mathrm{E} \\
24 \mathrm{H}\end{array}$ \\
\hline Toplam & 143 & 68 & $145 \mathrm{E} / 62 \mathrm{H}$ \\
\hline
\end{tabular}

Tablo 3 incelendiğinde K1, K3, K5, K6, K7, K9, K12 ve K13’ün kapak resminin karakterin duygu durumuyla ilişkili olduğu; K3, K12, K13’te kapak başlı̆̆ının, karakterin duygu durumuyla ilişkili olduğu görülmüştür. “Resim, metinde anlatılmak istenen duyguyu açıklar niteliktedir” ölçütünde en fazla “evet”in (10E) K12'de olduğu ve tüm kitaplarda toplam 67 evet 23 hayır olduğu tespit edilmiştir. "Metin, resimde anlatılmak istenen duyguyu açıklar niteliktedir" ölçütünde en fazla 
“evet”in (11E) K12'de olduğu ve tüm kitaplarda toplam 67 evet 24 hayır olduğu tespit edilmiştir. Tüm ölçütler bağlamında tüm kitaplar değerlendirildiğinde ise 143 “evet”e ve 68 "hayır”a ulaşıldığ1 saptanmıştır.

Kitap 1'e ait Şekil 4'te, ayakta kolları bağlı, yerde oturur pozisyonda bir elini yukarı kaldırmış, kaşları çatık şekilde kız çocuğu (Rita) ve bakışlarını kız çocuğuna yöneltmiş bir köpek resmedilmiştir. Resme ait metin "Küçük köpek yavrusu yanıt vermedi, ama kalbi hızlı hızlı attı: Tik tak, tik tak. Sanki köstekli saat." şeklindedir. Resim metindeki duygu durumunu yansıtmada yetersiz kalmaktadır. Çünkü metinde aktarılan kaygıdan ve korkudan kaynaklı yoğun heyecan yaşayan köpeği anlatan ifadeler resimden çok net okunmamaktadır. Bu durumda küçük okurların metin devreye girmeden karakterlerin duygu durumunu okumaları istendiğinde, kız çocuğun kızgın olduğunu düşünecekleri, köpek için ise yorum yapmakta zorlanacakları tahmin edilmektedir. Dolayısıyla metin, resmin tamamlayıcı olarak devreye girdiğinde bir anlam kazanacaktır.

Resim ve metin etkileşimi bağlamında kitap 4'e ait şekil 5 incelendiğinde, renkli bir filin (Emler) arkadaşlarıyla birlikte ormanda resmedildiği ve filin arkadaşlarının arasında yürüdüğü, arkadaşlarının da bir kabın içene renkli meyveleri koyup karıştırdığı görülmektedir. Bu görselde dikkat çeken en önemli ayrıntı, Elmer'ın diğer arkadaşları gibi gri renkte olmaması tam aksine rengarenk karelerden oluşan bir görüntüsünün olmasıdır. Ayrıca bu temsilde tüm fillerin koşuşturma içinde bir işle meşgul olduğu fakat Elmer'ın ise herhangi bir işe karışmayıp aralannda gezindiği görülmektedir. Karakterlerin duygu durumlarına bakıldığında hepsinin eğlenerek mutlu bir şekilde hareket halinde olduğu fark edilmektedir. Bu resim, çocukların tüm fillerin mutlu olduklarını ve fillerin işbirliğiyle eğlenerek bir şeyler yapmaya çalıştı̆̆ını görsel olarak okuyarak anlayabilecekleri açıklıktadır. Günlük yaşantıya bakıldığında çocukların, gerek okul gerek ev ortamında arkadaş veya aile üyeleriyle beraber bir etkinliği gerçekleştirdiklerinde kendilerini mutlu hissettikleri görülür. 66 aylık çocukların bu tarz bir deneyim yaşama olasılıklarının yüksek olduğu ve bundan dolayı karakterlerin zihnini okuyarak kendi dolaylı yaşantıları ile ilişkilendirip onların mutlu ve sevinçli olduklarını anlamaları açıtır. $\mathrm{Bu}$ sayfada fillerdeki bu hareketliliğin nedeni açıklanarak resim netlik kazanmış ve metin resmin tamamlayıcısı olarak devreye girmiştir. Metin; "Rengarenk fil Elmer, diğer arkadaşlarına baktı ve gülümsedi. Elmer Günü gelip çatmıstı. Elmer Günü’nde ormandaki tüm filler, y1lda bir kere kendilerini farklı desenlerle boyar ve geçit töreni yaparlardı. Filler, bu özel gün için henüz hazırlanmaya başlamışlardı. Çok heyecanlılardı ve bu süreçte oldukça fazla gürültü çıkarıyorlardı.” şeklindedir. 
Kitap 5'e ait Şekil 6'da, "Bu işe canı çok sıkılan çocuk güneşle açık açık konuşmaya karar vermiş..." şeklindeki metinde "can sıkıntısı" mutsuzluk göstergesidir fakat resimde çocuğun mutsuzluk içinde olduğunu anlamak güçtür. Resim ve metin etkileşimi net bir şekilde verilmemiş, bunun tam tersi olarak çocuk gülümser yani mutlu bir şekilde resmedilmiştir. Dişsal işaretlerin metinle örtüşmemesi 66 aylık çocukların zihin okumada ve empati kumada belirsizlik yaşayacağına işarettir.

Kitap 8'e ait Şekil 7'de “Ayı Monti mutlu mesut yollandı ormana doğru.” şeklindeki metinde ayının mutlu olduğuna dair bir anlam mevcuttur. Fakat resim metni açıklar nitelikte değildir. Resimde karda yol alan, arkası dönük bundan dolayı yüze ait dişsal işaretleri okunamayan bir ayı resmedilmiştir. Ayrıca ayı yalnız ve ayının başı öne doğru eğik şeklide çizilmiştir. Bu temsil hüzünlü olmaya daha fazla çağrışım yapmaktadır. Dolayısıyla resimden ayının duygu durumuna ilişkin bir yorum yapmak zordur. 66 aylık çocukların da metin ve resmi örtüştürmekte belirsizlik yaşayacağı ve buna bağlı ayının mutlu olduğunu anlama ve hissetme durumu güçleşecektir.

\section{Zihin okumada yansitma katmanlar1}

Kitaplardaki duygu ifadesi bulunan cümlelerdeki zihin okumada yansıtma katmalarının sayısal değerleri Tablo 4'te sunulmuştur.

Tablo 4. 13 resimli öykü kitabında zihin okumada yansıtma katmalarının sayısı

\begin{tabular}{|c|c|c|c|c|c|c|c|c|c|c|c|c|c|c|}
\hline $\begin{array}{l}\text { Zihin } \\
\text { Okumada } \\
\text { Yansitma } \\
\text { Katmanlar1 }\end{array}$ & $\mathrm{K} 1$ & $\mathrm{~K} 2$ & K3 & K4 & K5 & K6 & K7 & K8 & K9 & K10 & K11 & K12 & K13 & Toplam \\
\hline İkinci Sıra & 3 & 5 & 12 & 8 & 1 & 6 & 1 & 7 & 1 & 8 & 3 & 10 & 4 & 68 \\
\hline Üçüncü Sıra & & 1 & 5 & 2 & 14 & 10 & 3 & 8 & 8 & 3 & & 2 & 3 & 59 \\
\hline $\begin{array}{l}\text { Dördüncü } \\
\text { Sira }\end{array}$ & & 1 & & & 3 & & & & & & & & & 4 \\
\hline Toplam & 3 & 7 & 17 & 10 & 18 & 16 & 4 & 15 & 9 & 11 & 3 & 12 & 7 & 131 \\
\hline
\end{tabular}

Tablo 4 incelendiğinde resimli öykü kitaplarındaki duygu ifadelerinin geçtiği cümlelerde en fazla ikinci sırada (68) zihin okumada yansıtma katmanı olduğu görülmüştür. Bunun yanında üçüncü sırada (59) yansıtma katmanının ise yine nispeten fazla olduğu ortaya çıkmıştır. Cümlelerde az da olsa dördüncü sıra (4) zihin okuma katmanına da rastlanmıştır. K1'de üç tane ikinci sırada; K2'de beş tane ikinci, 1 tane üçüncü, 1 tane dördüncü sırada; K3'de 12 tane ikinci, beş tane üçüncü; K4'te sekiz tane ikinci, iki tane üçüncü; K5'te bir tane ikinci, on dört tane üçüncü, üç tane dördüncü; K6'da altı tane ikinci, on tane üçüncü; K7'de bir tane ikinci, üç tane üçüncü; K8'de yedi tane ikinci, sekiz tane üçüncü; K9'da bir tane ikinci, sekiz tane üçüncü; K10'da sekiz tane ikinci, üç tane üçüncü; K11'de üç tane ikinci sırada zihin okumada yansıtma katmanı tespit edilmiştir. 
İkinci sırada zihin okumada yansıtma katmanına en fazla sahip kitap K3 (12), üçüncü sırada zihin okumada yansıtma katmanına en fazla sahip kitap K5 (14), dördüncü sırada zihin okumada yansitma katmanına en fazla sahip kitap K5 (3)'dir.

İkinci sırada zihin okumada yansıtma katmanına en az sahip kitap K5 (1), üçüncü sırada zihin okumada yansıtma katmanına en az sahip kitap K2 (1)' dir. Dördüncü sırada zihin okumada yansitma katmanına sahip olmayan kitaplar; K1, K3, K4, K6, K7, K8 ve K9'dur. İkinci sirada okumada yansıtma katmanına sahip olmayan kitap ise K1'dir. Aşağıda bunlara ilişkin örnekler verilmiştir.

Kitap 1'de "Bugün doğum günü ama Rita'nın suratı asık!", ifadesinde zihin okumada yansıtma katmaları: Rita’nın kızgın olduğunu (ikinci sıra), okurun anlaması (birinci sıra) şeklindedir. Kitap 2'de "Annemle babam şaşkınlıkla bana baktılar." ifadesinde zihin okumada yansıtma katmaları: Anne, babanın şaşkınlığını (üçüncü sıra), çocuğunun anladığını (ikinci sıra), okurun anlaması (birinci sıra) şeklindedir. Kitap 3’te birinci örnek; “Kendini çok yalnız hisseden Kalben, balıklara yanaşıp 'Ben de sizinle yüzebilir miyim? diye fisıldamış." ifadesinde zihin okumada yansıtma katmanları: Kalben’in üzgün olduğunu (üçüncü sıra), balıkların anlamsını (ikinci sıra), okurun anlaması (birinci sıra) şeklindedir. Kitap 4’te “ 'Elmer senin çocuklar çok şamata yapıyor.' Diye uyardı Aslan.” ifadesinde zihin okumada yansıtma katmanları: Aslan'ın uyarısını (üçüncü sıra), Elmer'ın anladığını (ikinci sıra), okurun anlaması (birinci sıra) şeklindedir. Kitap 5'te "Çocuk yine sıkılarak dolaşırken sandalının içinde oturan bir adam ona neden bu kadar mutsuz olduğunu sormuş." ifadesindeki zihin okumada yansıtma katmanları: Çocuğun mutsuz olduğunu (dördüncü sıra), adamın anladığını (üçüncü sıra), diğer çocuğun anladığını (ikinci sıra), okurun anlaması (birinci sıra) şeklindedir.

\section{İkinci Çalışmaya İlişkin Bulgular}

Araştırmanın ikinci aşamasının temel amacı, Bilişsel Edebi Yaklaşım açısından resimli öykü kitaplarındaki duygu ifadelerinin 60-72 aylık çocuklardaki yansımasını incelemektir. Bu amaç doğrultusunda ortalama 66 aylık toplam 10 çocukla, "Eyvah! Kalbim Kırıldı” ve "Tuhaf Bir Gün” başlıklı iki resimli öykü kitabı kullanılarak görüşmeler yapılmış ve veriler toplamıştır. İlk aşamada sadece resimler gösterilmiş, ikinci aşamada ise resimlerle birlikte metin okunmuştur. Kitabın, kapak sayfası da dahil olmak üzere her bir sayfası için çocukların ifadeleri değerlendirilmiş ve Bilişsel Edebi Yaklaşımın kavramsal dayanakları (zihin okuma ve empati) çerçevesinde içerik analizleri yapılmıştır. Analiz sonucunda iki temaya ulaşılmıştır. Bunlar: (1) Resimlerdeki Duygu İfadelerinin Zihin Okuma ve Empati Yoluyla Çocuklardaki Yansımas1, (2) Metindeki Duygu İfadelerinin Zihin Okuma ve Empati Yoluyla Çocuklardaki Yansıması'dır. 


\section{Resimlerdeki duygu ifadelerinin zihin okuma ve empati yoluyla çocuklardaki yansıması}

Araştırmanın ilk teması olarak ortaya çıkan "Resimlerdeki Duygu İfadelerinin Zihin Okuma Becerisi ve Empati Yoluyla Çocuklardaki Yansıması”nda çocuklardan kapak sayfası dahil olmak üzere kitaptaki tüm resimleri incelemesi istemiştir. Çocukların resimlerdeki karakterlerin dışsal işaretlerinden faydalanarak duygu durumlarını nasıl ifade ettikleri araştırılmıştır. Kitap 1'in (Eyvah Kalbim Kırıldı!) ile Kitap 2'nin (Tuhaf Bir Gün) resimlerini inceleyen çocukların kullandıkları duygu ifadelerinin sayısı Tablo 5’te verilmiştir. Çocuklar, "Ç1, Ç2, Ç3, Ç4, Ç5, Ç6, Ç7, Ç8, Ç9, Ç10” şeklinde kodlanmıştır.

Tablo 5. Kitap 1'e ve Kitap 2'ye ait resimlerdeki duygulara ilişkin çocuk ifadelerinin sayıs1

\begin{tabular}{|c|c|c|c|c|c|c|c|c|c|c|c|c|}
\hline Duygular & & Ç1 & Ç2 & Ç3 & Ç4 & Ç5 & Ç6 & Ç7 & Ç8 & Ç9 & Ç10 & Toplam \\
\hline \multirow{2}{*}{$\begin{array}{l}\text { Mutluluk } \\
\text { /Sevinç }\end{array}$} & K1 & 4 & 3 & 5 & 4 & 4 & 4 & 2 & 4 & 5 & 4 & 39 \\
\hline & K2 & 14 & 15 & 13 & 14 & 14 & 15 & 15 & 14 & 15 & 15 & 144 \\
\hline \multirow{2}{*}{$\begin{array}{l}\text { Mutsuzluk/ } \\
\text { üzüntü }\end{array}$} & K1 & 7 & 9 & 7 & 5 & 6 & 6 & 7 & 7 & 7 & 3 & 64 \\
\hline & $\mathrm{K} 2$ & 1 & & & 1 & & 1 & & & & & 3 \\
\hline \multirow{2}{*}{$\begin{array}{l}\text { Öfke/ } \\
\text { Kızginlık }\end{array}$} & K1 & & & & & & & & & & & \\
\hline & $\mathrm{K} 2$ & & 1 & & & 1 & & 1 & 1 & 1 & 1 & 6 \\
\hline \multirow[t]{2}{*}{ Korku } & K1 & & & & & & & & & & & \\
\hline & $\mathrm{K} 2$ & & & 1 & & & 1 & & 1 & & & 2 \\
\hline \multirow[t]{2}{*}{ Sevgi/Assk } & K1 & & & & & & & & & & & \\
\hline & $\mathrm{K} 2$ & 2 & 1 & 1 & 2 & 2 & 2 & 2 & 2 & 2 & 1 & 17 \\
\hline \multirow[t]{2}{*}{ Şaşkınlık } & K1 & & & 1 & & & & & & & & 1 \\
\hline & $\mathrm{K} 2$ & 1 & 1 & & 1 & 1 & & 1 & & 1 & 1 & 7 \\
\hline \multirow[t]{2}{*}{ Belirsizlik } & K1 & 3 & 3 & 2 & 5 & 4 & 2 & 1 & 2 & 1 & 3 & 26 \\
\hline & $\mathrm{K} 2$ & & & & & & & & & & & \\
\hline
\end{tabular}

Tablo 5 incelendiğinde Kitap 1 için çocukların yapmıs olduğu yorumlardan en fazla "mutsuzluk" (64), ardından "mutluluk" (39) ve son olarak "şaşkınlık" (1) ; kitap 2'de ise çocukların en fazla“mutluluk" (144), ardından “sevgi” (17), "şaşkınlık" (7), "kızgınlık” (6) ve son olarak "korku” (2) duygusundan bahsettikleri ortaya çıkmıştır.

Kitap 1'de "Mutluluk" duygusundan en fazla Ç3 ve Ç9, "mutsuzluk" duygusundan en fazla Ç2, "şaşkınlık" duygusundan ise Ç3 bahsetmiştir. "Mutluluk" duygusundan en az Ç7, "mutsuzluk" duygusundan en az Ç10 bahsetmiştir. Kitap 1'de çocuk yorumları arasındaki bu değişikliğe kitap 2'de rastlanmamıştır. Kitap 2'de çocukların duygu ifadesi içeren sözcük sayılarının birbirine yakın olduğu görülmüştür. Örneğin; Ç2’nin, Ç6’nın, Ç7’nin, Ç9 ve Ç10’un mutluluk (sevinç) duygusundan 15 kez, Ç1, Ç5’in, Ç4’ün, Ç2, Ç7’nin, Ç9 ve Ç10’un “şaşkınlık” duygusundan bir kez bahsettiği görülmüştür.

Kitap 1'de resimlerdeki duyguyu ifade etmede en fazla belirsizlik (anlamadım, bilmiyorum, kafam karıştı şeklinde ifadeler kullanma ya da sessiz kalma gibi tepkiler verme) yaşayan ise Ç4, en az 
belirsizlik yaşayan ise Ç7 ve Ç9'dur. Belirsizlik ise toplamda 26 kez karşımıza çıkmaktadır. Kitap 2'de ise çocukların belisizlik durumundan hiç bahsetmediği saptanmıştır. Bu durum çocukların duygulara ilişkin alımlama yaparken ilgili şekilleri (resimleri) açık ve anlaşı1ır bulduklarını göstermektir. Bulguya ilişkin örnekler aşağıda sunulmuştur.

Kitap 1'e ait yukarıdaki resimde karakterin nasıl hissettiği sorusuna, Ç1, Ç6, Ç7, Ç5 ve Ç4 “Bilmiyorum”; Ç9, Ç8 “Mutsuz”; Ç2 “Cama çıkmış, denizlere bakıyor, hala üzgün.”; Ç3, Ç10 ise "Mutlu” şeklinde yanıt vermiştir. Çocuklardan ikisinin karakterin dışsal işaretlerini okuyamaması ve çocukların cevapları arasındaki bu zıtlı̆̆ın resmin duygu durumunu yansıtmada muğlak olmasından kaynakladığ1 söylenebilir.

Kitap 2'ye ait Şekil 12'deki resimde karakterlerin nasıl hissettikleri sorulduğunda çocukların hepsi çocuk karakterlerin şaşkın, annenin ve babanın ise mutlu gözüktügünü ifade etmiştir. Bu durum resimlerdeki dışsal işaretlerin çocuklar tarafindan rahatlıkla okunabildiğini göstermektedir.

Yapılan çalışmada çocukların karakterlerin duygu durumlarının nedenlerini açıklarken çoğunlukla kendi deneyimlerinden veya medyadan yararlandıklarını saptanmıştır. Örneğin; kitap 3'e ait şekil 13’te, karakterin neden üzgün hissettiği sorusuna Ç6 “Elindeki yapraktan.” diyerek farklı bir cevap vermiştir. Burada karakterin elindeki yaprağın bir üzüntü işareti olarak Ç6 tarafindan okunması dikkat çekicidir. Ç6'ya yaprağın neden bir üzüntü işareti olduğu sorulduğunda ise izlediği bir filmden bahsetmiştir. Filmdeki karakterin ağlarken elinde bir çiçek tuttuğunu söyleyen Ç6, medya aygıtları vasıtayla aktarılan duygu durumundan etkilenerek bilgiyi öykü kitabındaki karaktere yansıtmıştır.

Araştırmada bulgular, karakterlerin duygu durumlarını okuyan çocukların karakterlerin dışsal işaretlerinin belirsiz olduğu ya da görünmediği durumlarda resimdeki diğer dişsal işaretleri kullanarak karakterin duygu durumunu tahmin etmeye çalıştığı göstermiştir. Örneğin; Şekil 14'de elinde bir menekşeyle koşarken arkadan görünen kız çocuğunun neden koştuğu sorulduğunda çocuklar, yüzünü görmediği halde karakterin mutlu hissettiğini söylemiş ve mutluluğun nedenini kızın elinde tuttuğu çiçeğe bağlamıştır. Bu durum çocukların anılarında çiçek ve mutluluğun ödeş tutulduğu ve çiçeklerin de diğer güzel görünen pek çok nesne ve varlık gibi bir mutlu olma durumunu çağrıştırdığı gerçeğini ortaya koymaktadır.

Yapılan çalışmada çocukların duygu tanımlarının, yaşantı ve medya yoluyla varlıklara atfedilen duygusal algıdan kaynaklandığı tespit edilmiştir. Örneğin Şekil 15’teki görsel temsilde küçük okurlar, kız ve erkek çocuğun neden şaşkın sorusuna; Ç6, "Böyle bir şey (ejderi işaret ederek) görmedikleri için galiba.”, Ç10, "Böyle hanımefendi bir timsah gördükleri için.” Ç9, “Çünkü bunu (ejderi 
göstererek) gördükleri için”, Ç8, “Bir canavar gördükleri için”, ve Ç7, "Böyle bir canavar gördükleri için” şeklinde yanıt vermiştir. Çocuklar vermiş olduğu yanıtlarda, kız ve erkek çocuğun şaşkın olmasının nedenini daha önce böyle bir canlı görmemeleri şeklinde açıklamıştır. Çünkü bu canlıya (ejder, timsah, vb.) yaşantı veya medya yoluyla korku atfedilmiştir ve bu çocukların duygu algısını yönlendirmektedir. Araştırmadaki bir diğer bulgu ise çocuklar kitapta görmelerine karşın gerçekmiş gibi “ejder”den korktuklarını dile getirmişlerdir. Örneğin, Ç6, “Ay çok korktum!”, Ç3, “Kuyruğuyla bana vurur mu?”, Ç1, "Dişleri çok korkunçtur bence...”, Ç7, "Ben böyle bir bakıc1 istemem çünkü çok korktum." şeklinde tepkiler vermiştir.

Yapılan çalışmada bulgular resimli öykü kitaplarında empatinin çocukların anlatılara (kurgusal metinlere) olan tepkilerinde etkin rol oynadığını göstermiştir. Örneğin, Kitap 1'e ait Şekil 15'deki görsel temsilde çocuklara karakterin neden üzgün olduğu sorulduğunda Ç8, “Gözleri iyi görmediği için üzgün olabilir.” şeklinde yanıtlamıstır. Ç8'de gözlük kullanması öykü karakteriyle kendi durumunu benzeştirerek, karakterin iyi görememesinin bir üzüntü ya da yorgunluk nedeni olabileceği çıkarımıyla Ç8, bir zihin okuma ve empati becerisi göstermiştir. Bu soruya, Ç10 "Çünkü kar yağıyo ve ayakları çıplak geziyo dışarda" demiştir. Ç10’un görsel temsilde, havada uçuşan belli belirsiz beyaz bitki tohumlarını ya da tozları, kar tanesi olarak okuması ilgi çekicidir. Resmin görselinde bu küçük ayrıntı dışında kış veya sonbahar mevsimini çağrıştıran hiçbir temsil olmamasına rağmen, Ç10’nun araştırmacıyla görüşmenin yapıldığı kış mevsimi kurguya aktarmış ve karakterle empati kurmuştur.

\section{Metinlerdeki duygu ifadelerinin zihin okuma ve empati yoluyla çocuklardaki yansıması}

Kitap 1 (Eyvah Kalbim Kırıldı!) ve Kitap 2 (Tuhaf Bir Gün) 66 aylık çocuklara metin eşliğinde okunmuştur. Metinde geçen duygu ifadelerine ilişkin çocuklara sorular sorulmuştur. Çocukların kullandıkları duygu ifadeleri, bu ifadeleri tasvir etme ve karakterin duygu durumunu resim ve metin etkileşimiyle yorumlamaları değerlendirilmiştir. Tablo 10 'da çocukların sorulan sorulara vermiş olduğu yanıtlarda kullandıkları duygu ifadelerinin sayısı verilmiştir.

Tablo 6. Kitap 1 ve Kitap 2'de duygu ifadelerinin geçtiği metinlere ait çocuk ifadelerinin sayısı

\begin{tabular}{|c|c|c|c|c|c|c|c|c|c|c|c|c|}
\hline & & Ç1 & Ç2 & Ç3 & Ç4 & Ç5 & Ç6 & Ç7 & Ç8 & Ç9 & Ç10 & Toplam \\
\hline K1 & Ş1(üzüntü) & $\mathrm{X}$ & $\mathrm{X}$ & $\mathrm{X}$ & $\mathrm{X}$ & $\mathrm{X}$ & $\mathrm{X}$ & $\mathrm{X}$ & $\mathrm{X}$ & $\mathrm{X}$ & $\mathrm{X}$ & 10 \\
\hline K1 & Ş2(üzüntü) & & $\mathrm{X}$ & & & $\mathrm{X}$ & & $\mathrm{X}$ & & $\mathrm{X}$ & & 4 \\
\hline $\mathrm{K} 2$ & Ş2 (üzüntü) & $\mathrm{X}$ & $\mathrm{X}$ & $\mathrm{X}$ & $\mathrm{X}$ & $\mathrm{X}$ & $\mathrm{X}$ & $\mathrm{X}$ & $\mathrm{X}$ & $\mathrm{X}$ & $\mathrm{X}$ & 10 \\
\hline K1 & Ş3(üzüntü) & $\mathrm{X}$ & $\mathrm{X}$ & $\mathrm{X}$ & $\mathrm{X}$ & $\mathrm{X}$ & $\mathrm{X}$ & $\mathrm{X}$ & $\mathrm{X}$ & $\mathrm{X}$ & & 9 \\
\hline K1 & Ş4(üzüntü) & $\mathrm{X}$ & $\mathrm{X}$ & $\mathrm{X}$ & $\mathrm{X}$ & $\mathrm{X}$ & $\mathrm{X}$ & $\mathrm{X}$ & $\mathrm{X}$ & $\mathrm{X}$ & $\mathrm{X}$ & 10 \\
\hline K1 & $\begin{array}{l}\text { Ş5(üzüntü- } \\
\text { sevinç) }\end{array}$ & & & & & & $\mathrm{X}$ & & & & & 1 \\
\hline $\mathrm{K} 1$ & Ş6(üzüntü) & & $\mathrm{X}$ & & & & $\mathrm{X}$ & & $\mathrm{X}$ & & & 3 \\
\hline K1 & Ş7(üzüntü) & X & $\mathrm{X}$ & & & $\mathrm{X}$ & $\mathrm{X}$ & X & $\mathrm{X}$ & $\mathrm{X}$ & & 7 \\
\hline
\end{tabular}




\begin{tabular}{|c|c|c|c|c|c|c|c|c|c|c|c|c|}
\hline K1 & $\begin{array}{l}\text { Ş8(üzüntü- } 2 \\
\text { sevinç) }\end{array}$ & $\mathrm{X}$ & $\mathrm{X}$ & $\mathrm{X}$ & & $\mathrm{X}$ & $\mathrm{X}$ & $\mathrm{X}$ & $\mathrm{X}$ & $\mathrm{X}$ & & 8 \\
\hline K1 & Ş9(üzüntü) & $\mathrm{X}$ & $\mathrm{X}$ & $\mathrm{X}$ & & $\mathrm{X}$ & $\mathrm{X}$ & $\mathrm{X}$ & $\mathrm{X}$ & $\mathrm{X}$ & & 8 \\
\hline K1 & $\begin{array}{l}\text { Ş10(2 } \\
\text { üzüntü) }\end{array}$ & $\mathrm{X}$ & & & & $\mathrm{X}$ & $\mathrm{X}$ & & $\mathrm{X}$ & $\mathrm{X}$ & $\mathrm{X}$ & 6 \\
\hline K1 & $\begin{array}{l}\text { Ş11(2 } \\
\text { mutluluk) }\end{array}$ & $\mathrm{X}$ & $\mathrm{X}$ & $\mathrm{X}$ & $\mathrm{X}$ & $\mathrm{X}$ & $\mathrm{X}$ & $\mathrm{X}$ & $\mathrm{X}$ & & $\mathrm{X}$ & 9 \\
\hline K1 & $\begin{array}{l}\text { Ş12(3 } \\
\text { mutluluk) }\end{array}$ & & & & & & & & $\mathrm{X}$ & & & 1 \\
\hline $\mathrm{K} 2$ & $\begin{array}{l}\text { Ş12 } \\
\text { (mutluluk) }\end{array}$ & $\mathrm{X}$ & $\mathrm{X}$ & $\mathrm{X}$ & $\mathrm{X}$ & $\mathrm{X}$ & $\mathrm{X}$ & $\mathrm{X}$ & $\mathrm{X}$ & $\mathrm{X}$ & $\mathrm{X}$ & 10 \\
\hline K1 & $\begin{array}{l}\text { Ş13(2 } \\
\text { mutluluk) }\end{array}$ & & & $\mathrm{X}$ & $\mathrm{X}$ & & $\mathrm{X}$ & $\mathrm{X}$ & $\mathrm{X}$ & & & 5 \\
\hline K2 & Ş13 (sevgi) & $\mathrm{X}$ & $\mathrm{X}$ & $\mathrm{X}$ & $\mathrm{X}$ & $\mathrm{X}$ & $\mathrm{X}$ & $\mathrm{X}$ & $\mathrm{X}$ & $\mathrm{X}$ & $\mathrm{X}$ & 10 \\
\hline K1 & $\begin{array}{l}\text { Ş14(4 } \\
\text { mutluluk) }\end{array}$ & $\mathrm{X}$ & $\mathrm{X}$ & & & & $\mathrm{X}$ & $\mathrm{X}$ & $\mathrm{X}$ & & & 5 \\
\hline
\end{tabular}

Tablo 6 incelendiğinde Kitap 1'de tüm çocukların kapak başlığındaki (Eyvah Kalbim Kırıldı!) duygu durumunu tanımladığı ve görseldeki kız çocuğun "üzgün” olduğunu dile getirdiğini görülmektedir. Şekil 2'ye ait metinde geçen duygu ifadesine dört çocuk (Ç2, Ç5, Ç7, Ç9) yorum yapmıştır. Çocukların en çok Ş1 ve Ş4'e (10 kez) ardından, sırasıyla Ş3, Ş11 (9 kez), Ş8 ve Ş9 (8 kez), Ş7’ye (7 kez), yorum yaptığ1 görülmüştür. Çocukların en az yorum yaptığ1 metinler ise Ş5 ve Ş12’ye (1 kez) aittir. Metinlerdeki duygu ifadelerini en fazla Ç6'nın ve Ç8'in (12 kez) yorumladığı, en az Ç4'ün ve Ç10’un yorumladığı görülmektedir.

Kitap 2 ait Ş2'de mutsuzluk (üzüntü), Ş12'de mutluluk (sevinç) ve Ş13’te sevgi (aşk) duygularına ilişkin ifadeler bulunmaktadır. Şekillere ait metinlerde geçen duygu ifadelerine tüm çocukların duygu ifadelerini tanımlayarak yorumlar yaptığı görülmektedir.

Kitap 1'deki şekillere ait metinler için çocukların duygu ifadesi kullanma sayılarının az olduğu (Ş2, Ş5, Ş6, Ş12, Ş13, Ş14) fakat Kitap 2'deki şekillere ait metinler için tüm çocukların duygu ifadesi kullandığı görülmektedir. Bu durum kitap 2'nin Kitap 1'e kıyasla çocukların empati kurma ve zihin okumaya daha fazla olanak sağladığını göstermektedir.

Bulgular, Kitap 1'deki duygu içeren sözcük ve sözcük gruplarının daha çok soyut kelimeler ve deyimlerle ifade edildiğini ortaya çıkarmıştır. Örneğin; "Kalben'in kalbi hala kırıktı.”, "Kalbi biraz yumuşamıştı.", "Kalbini nasıl tamir edeceğini düşünmüş.”, "Kırık kalbe iyi gelir.”, "Kalbini bir yumuşaklık kaplamış" gibi soyut ifadeler kullanılarak mutsuzluk dile getirilmiştir. Çocuklardan üçü bu ifadelerin üzüntü barındırdığını anlamış diğerleri ise anlamamıştır. Üç çocuğun anlamasının nedeni metne eşlik eden resmin, çocukların zihin okumasını ve empati kurmasını kolaylaştırmasıdır. Diğer çocukların anlamasının nedeni ise metnin, resmin tamamlayıcı olarak devreye girse de yeterince açık olmaması ve bu soyut ifadelerin yetişkin tarafindan çocuğa açıklanmasına ihtiyaç duyulmasıdır. 
Çalışmada bulgular, çocukların karakterlerin duygu durumlarının nedenlerini açıklarken çoğunlukla kendi deneyimlerinden veya medyadan yararlandıkları göstermiştir. Örneğin, Kitap 1'e ait Şekil 15'de, karakterin neden üzgün hissettiği sorusuna Ç6 "Elindeki yapraktan.” diyerek farklı bir cevap vermiştir. Burada karakterin elindeki yaprağın bir üzüntü işareti olarak Ç6 tarafindan okunması dikkat çekicidir. Ç6’ya yaprağın neden bir üzüntü işareti olduğu sorulduğunda ise izlediği bir filmden bahsetmiştir. Filmdeki karakterin ağlarken elinde bir çiçek tuttuğunu söyleyen Ç6, medya aygıtları vasıtayla aktarılan duygu durumundan etkilenerek bilgiyi öykü kitabındaki karaktere yansıtmıştır.

Bulgularda, çocuklar etkileşim içinde olduğu Kitap 1 ve Kitap 2'deki görsel temsili okurken ve yazılı metni dinlerken soyut ifadeleri tanımlamış ve yorum yapmışlardır. Örneğin; Kitap 1'de sevinç (mutluluk) duygusuna işaret eden "Kalbin pır pır atması"nı tanımlarken, Ç4, "Mutlu!”, Ç3 “Mutlu olmak.” şeklinde yorum yapmıştır. "Kalbin sağlam olması ne demek?” sorusuna Ç4, "Mutlu!”, Ç3 "Daha mutlu olmak", "Kalbin ilacı ne demek?” sorusuna "Süt!” şeklinde yanıt vermiştir. Ç3’ün "kalbin sağlam olması" deyimini açıklarken mutluk duygusunu derecelendirerek ve kabin ilacını süt olarak tanımlamıştır.

\section{SONUÇ ve TARTIŞMA}

\section{Birinci Çalışmaya İlişkin Tartışma}

Bu çalışmada 13 resimli öykü kitabı Bilişsel Edebi Yaklaşım ışı̆̆ında duygu durumlarını yansıtması açısından incelenmiştir. İncelenen resimli öykü kitaplarında ortaya çıkan bulgular (1) Resimde Zihin Okuma ve Empatinin Yansiması (2) Metinde Zihin Okuma ve Empatinin Yansıması (3) Resim ve Metin Etkileşimiyle Duyguların Yansıması (4) Metinde Zihin Okumada Yansıtma Katmanları başlıkları altında tartışılmıştır.

\section{Resimde zihin okuma ve empatinin yansıması}

Araştırma bulguları, resimli öykü kitaplarında resimlerin görsel gücü ve iletilmek istenen mesajın daha çok resimle aktarılmaya çalışıldığını göstermiştir. Bulgular, resimli öykü kitabında en fazla “mutluluk (sevinç)" duygusunun, en az "korku” ve "şaşkınlık" duygularının görselleştirildiğini ortaya çıkarmıştır. Bu durum, "mutluluk" duygusuna ilişkin dışsal işaretlerin yazar ve resimleyen tarafından daha çok tercih edildiğini ve çocuklara daha çok mutluluğa ilişkin mesajın aktarılmaya çalıştığını gösterirken "korku" ve "şaşkınlığa" ilişkin dışsal işaretlerin daha az tercih edildiğini göstermektedir. Benzer şekilde Alper (2012), "Resimli Kitaplardaki Karakterlerin Duygu Durumlarının İncelenmesi” konulu çalışmasında 112 resimli kitapta karakterlerin en fazla "sevinç" en az "öfke" duygusuyla resmedildiğini saptanmıştır. 
Araştırma bulguları, zihin okuma ve empati kurmaya olanak sağlaması açısından resimli öykü kitaplar değerlendirildiğinde "belirsizlik" yaratan çizimlerin nispeten fazla olduğu ortaya koymuştur. Kitapların beşinde duygu durumunu yansıtması açısından birtakım belirsizliklerin daha yoğunlukta olduğu (K3, K5, K8, K10 ve K11) ve duygu durumlarını tam olarak yansıtmadığ1 saptanırken, diğer kitaplarda bu durumun aksine duygu durumlarının daha açık bir şekilde yansıtıldığı ve daha anlaşılır mesajlar verildiği saptanmıştır. Benzer şekilde Nikolajeva (2013), "belirsizliğị” dışsal işaretlerin (mimik ve jetlerin) birden fazla duygu ifadesi barındırarak veya duygusal anlamlandırmada yetersiz kalarak görsel okuma sırasında doğru duygu durumunu saptamada muğlak kalması şeklinde tanımlarken "belirsizliğin" kitapların çocukların zihin dünyasında anlamlandırılması ve empati kurmaya olanak sağlamasında güçlük yarattığını ifade etmektedir. Ayrıca Gürel (2006), resimli kitapların düşünce ve duygu gelişimindeki etkin rolüne vurgu yapmış ve duygu durumları belirsiz olan karakterlerin, çocukların duygu gelişiminde olumsuz etki yaratabileceğini söylemiştir.

Bulgular ayrıca resimlerin duygu durumlarını aktarmada ve çocuklarda gelişmekte zihin okuma ve empati becerisine katkı sunmada önemli bir araç olduğunu vurgulamıştır. Resimlerin, yapılan diğer pek çok çalışmada önemli bir ileti aktarım aracı olarak kullanıldığı belirtilmiştir. Benzer şeklide Kiefer (1993), resimli kitapların değerlendirilmesinde içeriğin görsel anlatımı ve elde edilecek duygusal deneyimin önemine vurgu yapmıs ve sanatçlar tarafından doğru görsel temsiler ve seçimlerin yapılması gerektiğini belirtmiştir. Wohlgemuth (1998), çocukların metnin bağlamını, resimleri yani görsel metinleri kendi başlarına okurken öğrendiğini dile getirmiştir.

Yapılan çalışmada bulgular, öykülerdeki dışsal işaretlerin birden fazla duygu nüansına gönderme yapabileceğini (örneğin mutsuzluk, can sıkıntısı, isteksizlik, vb ) ortaya çıkarmıştır. Bunun da küçük okurlara bakış açısı çeşitliliği sunacağı ortaya konmuştur. Benzer şekilde Hakemulder (2000), kurgunun okura çeşitli bakış açıları sağlayarak “ötekini” anlamayı kolaylaştırmada önemli bir rol oynayabileceğini vurgulamıştır.

Araştırma bulguları, öyküdeki kahramanların dışsal işaretlerindeki mesajın gerçek hayattaki sosyal yaşamın ve sosyal ağın bir parçası olarak temsil edildiğine işaret etmiştir. Bu durum kurgu üzerindeki sosyo-bilişsel bakış açısını yani, edebi karakterlerin aynı gerçek karakterler gibi bir sosyal ağın parçası olduğu ve bu yüzden ortak düşünce ve davranış sergilediği gerçeğine odaklanıldığını göstermektedir. Bu bakış açısını Palmer (2005), "Romanda Zihinler Arası Düşünce: Middlemarch Aklı" adlı kitabında romanlarda meydana gelen zihinsel işlevin çoğunun büyük organizasyonlar, küçük gruplar, iş arkadaşları, arkadaşlar, aileler, çiftler ve öteki zihinler arası birimler tarafından yapıldığını belirterek desteklediği görülmektedir. 


\section{Metinde zihin okuma ve empatinin yansıması}

Yapılan çalışmada bulgular, resimli öykü kitaplarında, metinlerdeki sözcük veya sözcük gruplarındaki duygu ifadelerinin temel duygu ifadeleri (kızdı, mutlu oldu, şaşırdım, korktum, vb.) ve dolaylı/soyut olarak temel duygulara gönderme yapan ifadeler (kalbim kırıldı, gözler fal taşı gibi açıldı, ödü patladı, bayılırım, vb.) olduğunu göstermiştir. Bu durum 60-72 aylık çocukların "kızmak, sevinmek, ağlamak, korkmak, vb” duygu ifadelerini, anlayabileceğini fakat "ödü patladı, gözleri fal taşı gibi açıldı, vb.” gibi duygu ifadelerini anlayamayacağını göstermektedir. Bu 60-72 aylık çocukların metni anlamsının önüne geçerek zihin okuma ve empati kurmasını güçleştirmektedir. Metinde geçen bu deyimlerin çocuğa açıklanarak somutlaştırılması gerekmektedir. $\mathrm{Bu}$ somutlaştırmalar ve açıklamalar çocukların, karakterlerin duygu durumlarını anlayarak zihni okumasını ve empati kurmasını kolaylaştıracaktır. Benzer şekilde çocukları yeni sözcük ve sözcük gruplarıyla tanıştırmanın faydalı olduğunu ifade eden Tokgöz (2006), 66 aylık çocukların dil gelişimini desteklenmesi ve çocukları anlambilimsel yönden de destekleyen kitapların yayımlanması gerektiğine vurgu yapmıştır. Tekin ve Tekin de (2006), yapmış oldukları çalışmada, resimli kitapların çocukların kelime dağarcıklarını geliştirdiğini ifade etmişlerdir.

Araştırma sonuçları ayrıca, resimli öykü kitaplarındaki metinlerde "mutluluk" ve "üzüntü" duygularının yoğunlukta işlendiği diğer temel duygular olan "öfkenin”, "korkunun”, "sevginin” ve "şaşkınlığın" ise metinde daha az ifade edildiğini göstermiştir. Bu durum, "mutluluk" ve "mutsuzluk" duygusuna ilişkin sözcük veya sözcük gruplarının yazar tarafindan daha çok tercih edildiğini ve çocuklara metin yoluyla daha çok "mutluluk" ve "mutsuzluk" duygusuna ilişkin mesajın aktarılmaya çalıştığını gösterirken "korku”, "şaşkınlık” ve "aşk (sevgi)" duygusuna ilişkin sözcük veya sözcük gruplarının daha az tercih edildiğini göstermektedir. Benzer şekilde Alper (2012), yaptığı çalışma sonucunda resimli kitaplardaki karakterlerin en fazla sahip olduğu duygu durumunun metinde "sevinç" duygusu en az "şaşkınlık" duygusu olduğunu tespit etmiştir.

\section{Resim ve metin etkileşimiyle duyguların yansıması}

Araştırma bulguları, sekiz kitabın kapak resminin karakterin duygu durumuyla ilişkili olduğu, beş kitabın ise ilişkili olmadığını göstermiştir. Kapak resminin karakterin duygu durumuyla ilişkili olması çocukların karakterin duygu durumunu hissetmesini ve anlamasını kolaylaştırmakta ve çocukların empati ve zihin okuma becerisini kullanmasına yardımcı olmaktadır. Nikolajeva (2012), kitabın ilk görsel temsilinin ve çocuğu kitaba çeken ilk uyaranın kitabın kapak resmi olduğunu ve karakter/lerin açık ve anlaşılır şekilde resmedilmiş olmasının önemli olduğunu dile getirmiştir. 
Araştırma bulguları, üç kitabın kapak başlı̆̆ının, karakterin duygu durumuyla ilişkili olduğu, on kitabın ise ilişkili olmadığını göstermiştir. Kapak resmi duygu ifade eder şekilde resmedilmiş ise kapak başlığının bu duyguya atıfta bulunması her zaman bir gereklilik değildir. Fakat kapak başlığı örneğin, "Utangaç Ayı Monti” şeklinde doğrudan bir duygu ifadesi barındırıyor ise kapak resmiyle örtüşmek durumundadır. Kapak resmi, başlığı destekler şekilde ayının utangaç olduğunu hissettirecek açılıkta ve zihin okuma hizmet edecek kolaylıkta olmalıdır.

Yapılan çalışmada bulgular, "Resim, metinde anlatılmak istenen duyguyu açılar niteliktedir" ölçütünde en fazla “evet”in (10E) K12'de olduğu ve tüm kitaplarda toplam 67 evet 23 hayır olduğunu göstermektedir. Bulgular, "Metin, resimde anlatılmak istenen duyguyu açıklar niteliktedir” ölçütünde ise en fazla “evet”'in (11E) yine K12'de olduğu ve tüm kitaplarda toplam 67 evet 24 hayır olduğuna işaret etmektedir. Tüm ölçütler bağlamında 13 kitap değerlendirildiğinde ise 143 "evet"e ve 68 "hayır"a ulaşıldığ1 saptanmıştır. Sonuçlar resim ve metin arasındaki etkileşimin varlığından bahsetmektedir. Fakat bu etkileşimin daha belirgin ve nitelikli hale gelmesi gerektiğini vurgulamaktadır. Çünkü 68 kez "hayır" nispeten yüksek sayısal bir veridir. Bulgular, resim ve metinin, duyguları 60-72 aylık küçük okurlara aktarmada birbirlerini tamamlaması ve etkileşim içinde olması gerektiğe vurgu yapmaktadır. Nitekim, bu konuda çalısma yapan araştırmacılar da resim ve metin arasındaki etkileşime ve bütünlüğe vurgu yapmaktadır. Nodelman (1996), resimli kitabın sözel anlatım, resimsel anlatım ve her ikisinin bileşiminden kaynaklanan anlatım olmak üzere üç farklı anlatım şekli olduğunu söylemektedir; bu noktada önemli olan başarılı bir resim ve metin birleşiminde her iki yapının da bir bütün olarak algılanması olduğunu vurgulamıştır (Akt. Klemin, 1966). Pantaleo (2005), ve resim-metin ilişkisinin bir bütünün parçaları olarak etkileşim göstermeleri gerektiğini belirtmiştir. Ayrıca Nodelman, metindeki konu bütünlüğü ile resimlemedeki tasarım bütünlüğ̈̈nün mesajın okuyucu tarafindan dolaysız ve kalıcı bir şekilde algılanmasını sağladığını ifade etmiştir. Schnotz da (2002), metinde anlatılan konu ile resimlemelerde gösterilenin anlamsal tutarlılığın karşılıklı eşleşme sürecine dayadığını vurgulamıştır. Bu süreçte tasvir edilen konunun zihinsel bir modelini oluşturan okuyucu resimden anlarken de görsel uzamsal ilişkiler sistemiyle anlamsal ilişkiler kurduğunu belirtmektedir. Dolayısıyla yapılan bu çalışmada da hikâyede iletilen duygu durumunun betimlenmesinde metne ait yapı ile resme ait yapının anlamsal ve biçimsel olarak birbiriyle tutarlı olması gerektiği vurgulanmaktadır. Greenhoot ve Semb (2008), öykü kitaplarındaki resimlerin yorumlanmasının hem görsel hem de metne dayalı kaynaklardan gelen bilgilerin kaynaştırılmasıyla yapılabileceği ve bu sırada resimlerdeki detayların önem kazandığı dile getirmiştir.

Yapılan çalışmada bulgular, 13 resimli öykü kitabın içinde altı kitapta, özellikle toplumsal duyguları aktarma noktasında resmin açıklamadığı veya açılkayamadığı duygu ifadelerini metin aracılığıyla 
aktarmaya çalışıldığı göstermiştir. Diğer beş kitapta ise resim ve metin arasında etkileşimin sınırlı düzeyde olduğu, temel ve toplumsal duyguların aktarımının istenilen düzeyde olmadığ1 saptanmıştır. Bu durum küçük okurların öykü kurgusunu anlayarak karakterlerin duygu durumlarını hissetmesini ve anlamasını güçleştirmektedir. Aynı şekilde Nikolajeva (2013), resimli kitaplarda resimlerden tüm duygu durumlarını özellikle toplumsal duyguları anlatmanın zorluğu dile getirilmiş ve bu durumda metin devreye girmesi ve resimlerle anlatılamayan duygu durumlarını ifade etmesi gerektiğini belirtmiştir.

Ayrıca bulgular, resim ve metin arasındaki etkileşimin resimli öykü kitapları yoluyla duygu durumlanının anlaşılmasının zihin okuma ve empati gibi insan düşüncesinin etrafinda şekillenmesinde belirleyici bir role sahip olduğu ortaya çıkarmıştır. Karakterlerin duygu durumlarını anlama zihin okuma ve empati becerisine sahip olma koşuluna bağlıdır. Ayrıca yapılan araştırma, resim ve metin yoluyla aktarılan duyguların okur tarafindan anlaşılmasında ve yorumlanmasında kurgunun, insan düşüncesince şekillendiğini göstermektedir. Benzer şekilde Gerrig (2005), insan düşüncesinin hikayeler etrafında önemli bir şekilde biçimlendirildiğini ifade etmiştir. Bu bakımdan, dünyayı nasıl anlamlandırdığımızın içsel bir açısı olan anlatının, bilişsel anlatıbilimciler tarafından insan bilişselliğinin daha bütüncül bir resmine ulaşmak için kullanılması yoluna gidildiği belirtilmiştir (Herman 2003).

\section{Metinde zihin okumada yansıtma katmanlar1}

Yapılan araştırmada bulgular, çalışma grubundaki 13 resimli kitabın metindeki zihin okumada yansıtma katmanlarının yani niyetsellik basamaklarının sırasıyla en fazla ikinci, üçüncü ve nadiren dördüncü basamakta olduğunu göstermektedir. Dolayısıyla ikinci sırada zihin okumada yansıtma katmanına sahip olan kitapların çocuklar tarafından daha kolay anlaşılabileceği söylenebilir. Üçüncü ve dördünce sıradaki yansıtma katmanları nispeten daha karmaşık olduğu için çocuklar tarafından anlaş1ırlığının daha zor olduğu düşünülmektedir. Bu konuda çalışma yapan Palmer (2005) ve Dunbar (2000), yetişkinlerin beyinlerinin üç yada dört dizinli, iç içe girmiş zihin okuma sürecini yönettiğini iddia ederken çocukların iki dizinin ötesine gidemeyeceği öne sürmektedir. Aynı şekilde (Nikolajeva, 2013) 60-72 aylık çocukların en kolay ikinci sıradaki yansıtma katmanlarını anladığ1 ifade etmektedir.

Yapılan araştırma niyetsellik basamaklarının resimli öykü kitaplarında ikinci seviyenin üstünde olmasının çocukların zihin okuma yetneklerini zorlaması açısından faydalı olduğu göstermektedir. Benzer şekilde Zunshine (2006), kitaplarda zihin okuma yeteneği niyet seviyelerinin arttırılması ile mümkün olduğunu dile getirmekte ve okuyucuların başkalarının zihinlerini okuma yeteneklerini 
zorlanabilsin ve test edilebilsin diye niyet seviyelerinin anlatı kurgusunda çoğaltılabileceğini önermektedir. Ayrıca David Herman (2009), durumları deneyimlemenin nasıl bir şey olduğunun örneklerini ve olayların birleştirilebileceğini, karşılaştırılarak değerlendirilebileceğini ve dünyayla ilgili diğer söylemler için olayların faktör haline getirilebileceği bir çevre yaratmak için anlatının eşsiz kapasitesini vurgulayarak anlatı ve kişinin tecrübesinin niteliği arasındaki bağa vurgu yapmıştır.

\section{İkinci Çalışmaya İlişkin Tartışma}

İkinci çalışmada Bilişsel Edebi Yaklaşım açısından incelenen “Eyvah Kalbim Kırıldı!” ve “Tuhaf Bir Gün” isimli öykü kitapları çocuklara ilk aşamada sadece resimleri gösterilerek sorular soruşmuş daha sonra metin resme eşlik ederek okunmuş ve sorular sorulmuştur. Elde edilen bulgular (1) Resimlerdeki Duygu İfadelerinin Çocuklardaki Yansıması (2) Metinlerdeki Duygu İfadelerinin Çocuklardaki Yansıması, başlıkları altında tartı̧ıllmıştır.

\section{Resimlerdeki duygu ifadelerinin çocuklardaki yansıması}

Araştırma bulguları, Kitap 1'de çocukların en fazla "mutsuzluk", ardından "mutluluk" ve son olarak “şaşkınlık”; Kitap 2'de ise çocukların en fazla“mutluluk”, ardından “sevgi”, “şaşkınlık”, "kızgınlık” ve son olarak "korku" duygusundan bahsettikleri ortaya çıkmıstır. Çocuklardaki bu yansıma resmilerdeki karakterlerin dışsal işaretleriyle yakından ilişkilidir. Kitap 1'de yoğunlukta mutsuzluk duygusu, Kitap 2'de ise yoğunlukta "mutluluk" duygusu resmedilmiştir ve çocukların resimleri yorumlamaları da kitaplardaki görsel ile paralellik göstermektedir.

Araştırma bulguları, ayrıca Kitap 1'de çocukların yorumları arasında farklılıklar olduğunu fakat Kitap 2'de bu farklılığa rastlanmadığını ortaya çıkarmıştır. Kitap 1'deki çocukların 26 kez belirsizlikten bahsettiğini (anlamadım, bilmiyorum, kafam karıştı şeklinde ifadeler kullanma ya da sessiz kalma gibi tepkiler verme), Kitap 2'de ise çocukların belirsizlik durumundan hiç bahsetmediğini saptanmıştır. Bu durum açık ve anlaşılır dışsal işaretlerin çocuklar tarafindan daha kolay yorumladığına ve bu bağlamada empati ve zihin okuma becerisini geliştirmeye hizmet ettiğine işaret etmektedir. Benzer şekilde Nikolajeva (2012), resimli kitaplardaki net ve açık görsel temsillerin kişinin beyninde direkt ve öncelikli olarak duyguları tetiklediğinden bahsetmiş bunun da empati ve zihin okumayı kolaylaştırdığını dile getirmiştir.

Yapılan çalışmada bulgular, karakterlerin duygu durumlarını okuyan çocukların karakterlerin dışsal işaretlerinin belirsiz olduğu ya da görünmediği durumlarda resimdeki diğer dişsal işaretleri kullanarak karakterin duygu durumunu tahmin etmeye çalıştığını göstermiştir. Bu çocukların kendi yaşantılarında öğrenme yoluyla nesne ve varllklara duygu atfettiklerini göstermektedir. Benzer 
şekilde Nikolajeva (2012), çocukların resimlerdeki duygu ifadelerini görseldeki diğer varlıkları kullanarak anlamlandırabildiğini ifadede etmektedir. Örneğin, parlak gün ışı̆̆ındaki bir mekan veya şirin bir hayvan resmi gören bir çocuğun mutlu hissettiği bunun yanında karanlık bir orman gördüğünde ise korku duygusunu deneyimlediğini dile getirmiştir.

Bulgular, çocukların zaman zaman, görsel temsilin gerçek hayattakinden farkını algılamakta güçlük yaşadığını göstermiştir. Nikolajeva (2013), bunu kurgu ile gerçek arasındaki güçlü bağın varlığıyla açıklayarak çocukların duygu tanımlarının, yaşantı ve medya yoluyla varlıklara atfedilen duygusal algıdan kaynaklandığını ifade etmektedir. Bir canlıya (ejder, timsah, vb.) yaşantı veya medya yoluyla duygu atfedilmiştir ve bu durum çocukların duygu algısını yönlendirmektedir.

Araştırma bulguları, çocukların karakterin görsel temsiline gerçekmiş gibi tepki verdiklerini göstermiştir. Çalışmada karşılaşılan bu durum 60-72 aylık çocukların, görsel temsilinin gerçek hayattakinden farkını algılayamadıklarına işaret etmektedir. Bu tespite paralel olarak Nikoljeva (2013), bir canavarın görsel temsilinin gerçek hayattaki gerçek bir canavarla tıpatıp aynı olmasa da, böylesi tepkilerin gerçek hayattakinden çok da farklı olmadığını dile getirmektedir. Benzer şekilde Vermeule (2010) ve Zunshine (2006), resimli kitapta, mutlu bir yüz görünce gülümseyen, karakterin koştuğunu zıpladığını gördügünde hareket etmeye başlayan veya yutmaya hazırlanan dinozorun dişlerini gördüğünde titreyen küçük yaştaki bir çocuğun onlar gerçekmiş gibi duygularını yaşadığını belirtmiştir.

Yapılan çalışmada bulgular, çocukların resimli öykü kitaplarındaki karakterlerle empati kurmaya çalıştığını ve bunu en iyi Kitap 2'de gerçekleştirdiklerini göstermiştir. Araştırmacılar yaptıkları çalışmalarda, "duygusal bulaşma”" (Hess \& Blairy, 2001; Hess, Hatfield \& Chentob, 2008) olarak da ifade ettikleri empatinin çocukların anlatılara (kurgusal metinlere) olan tepkilerinde etkin rol oynadığını göstermiştir.

\section{Metinlerdeki duygu ifadelerinin çocuklardaki yansıması}

Yapılan çalışmada bulgular, çocukların bazı durumda sadece resimlere bakarak yaptığı yorumların yetersiz veya belirsiz olduğunu göstermiştir. Bu durum, resimlemelerin bilişsel ilkelere göre organize edilmiş olmasının sadece resimden veya sadece metinden kavramanın anlamlı sonuçlar ortaya koyabilmesi için tek başına yeterli olmadığını ortaya koymuştur. Tepecik ve Kayabekir (2017), resimlemelerin metnin anlamsal yapısıyla eşleşebilmesi için yapısal kavramlara göre de organize edilmesinin önemli olduğunu ve metinde yer alan konu, olay/olay örüntüsü, karakterler, zaman ve mekân kurgusunun bu eşleşmeyi organize edebilecek veriler sunduğunu dile getirmiştir. 
Araştırma bulguları, çocukların karakterlerin duygu durumlarının nedenlerini açıklarken çoğunlukla kendi deneyimlerinden veya medyadan yararlandıkları saptanmıştır. Bu bulguya paralel olarak Bordwell (1989), bilişsel teorideki yapısal yaklaşımın, bazı temel verilerin, ilkelerin ve varsayımların zihinde daha önceden var olduğunu dile getirmiştir. Bunun her zaman zihinde var olan bilgilere göre sonuçlar üreten algılama sisteminin, dışarıdan alınan görsel bilgileri zihinde var olan diğer bilgilerle karşılaştırarak mantıklı sonuçlar üretmeye çalıştı̆̆ından kaynakladığı belirtilmiştir (Akt. Özcan, 2004). Ayrıca bu durum, medyanın çocukları öykü kahramanlarının zihnini okumada etkili bir araç olduğunu göstermektedir. Keen, (2010) ve Armstrong (2013) kitaplardaki ve filmlerdeki anlatıların duygularımızı yönlendirdiği ve zaten kapasitemizde olan diğerleriyle birlikte hissetme özelliğimizi ortaya çıkardığı vurgulanmıştır. Ayrıca, televizyonda acı veren gerçek bir olayı izleyen herhangi birinin hatırlayabileceği gibi diğerlerinin hislerini anlamamız için orada olmamıza gerek olmadığını dile getirmişlerdir. Bizlerin duyguları hatırlatan hikaye, düzyazı ve film kurgusu anlatımına veya medya yayınlarına maruz kaldığımızda kurgusal karakterlerle ve uzaktan yabancı kimselerle birlikte hissedebildiğimizi belirtmişlerdir.

Yapılan çalışmada bulgurlar, metin ve resim yoluyla uyarılan anlatının (kurgusal metin) empatiyi bilişsel bir durumla ortaya çıkardığı desteklemiştir. Bunun nedeni “okumanın” karmaşık bilişsel işlemlere dayanmasıdır. Görsel temsilden çıkarılan tüm duygu durumları 60-72 aylık küçük okurların bilişsel anlamlandırmalarla empati kurduğunu göstermektedir. Bilişsel edebi teorisyen Lisa Zunshine (2015), yazılı kurgusal metinlerin, insanları hissetmeye davet ettiğinde aynı zamanda okuyucuların düşüncesini de uyardığını dile getirmiştir. Bu uyanış okuyucunun empatisini harekete geçirme noktasında önemli bir sıçrayışı ortaya çıkarmaktadır. İnsanların hayali dünyalarla entelektüel ve duygusal olarak ilgilenme kapasitesi; anlatı empatisini, estetiğin, psikolojinin ve felsefenin kesişme noktalarına yerleştirmektedir. Ayrıca Zunshine (2015), kurgunun eğlencesinin ya da insanı çeken tarafinın potansiyel olarak insanlarda mevcut olduğu ve karakterlerin zihinsel durumlarını 'deneme’ farkındalığına bağlı olduğunu söylemektedir. İnsanların bakış açıları ve motivasyonları, okurların dikkatini cezp ederken, karakterlerin zihinsel ve duygusal durumlarının kurgusallığı, okurun katılımı ve eğlenceli uğraşını davetkâr hale getirmektedir (Zunzhine, 2015). Araştırma bulgularına paralel olarak Sever (2003), okul öncesi dönemde çocuğun, dilsel iletileri dinleyerek anlamak durumunda olduğunu fakat buna karşın, görsel iletilerle, bir başkasına gerek duymadan birebir iletişim kurabildiğini ifade etmiştir. Çocukların ilk karşılaştığı uyaranların yaşam boyu kalıcı etkisi düşünüldüğünde, resimli öykü kitaplarının çok önemli bir dönüm noktasında olduğu söylenebilir. Yapılan çalışma, çocukların etkileşim içinde olduğu kitaplardaki görsel ve sözel temsilleri okurken yaptıkları tanımlamalar, yorumlar ve verdikleri cevaplar bu önemli etkinin izlerini yansitmaktadir. 
Sonuç olarak araştırma bulguları, Bilişsel Edebi Yaklaşım açısından resimli öykü kitaplarının çocukların dışsal işaretleri okuyarak öykü kahramanlarının duygu durumlarını anlama, bu duygu durumlannın nedenlerini tahmin etme, kendi duygularını ifade etme, metinde geçen duygu durumuyla kahramanın görünen duygu ifadesi arasında bağ kurma ve anlamlandırma yaparak zihin okuma ve empati kurma yetenekleri üzerinde olumlu etkilerini olduğunu ortaya koymaktadır.

Araştırma bulguları ve sonuçları göz önüne alınarak uygulamalar ve ileride yapılması planlanan araştırmalara yönelik şu önerilerde bulunulabilir:

- Resimli öykü kitaplarının zihin okuma ve empati gelişimine dair taşıdığı zenginliğin ebeveynler ve eğitimciler tarafindan fark edilmesinin sağlanması üzerinde durulmalıdır.

- Ebeveynler ve eğitimciler çocuklar için kitap seçerken daha hassas davranarak kitab1 pek çok açıdan değerlendirme becerisine sahip olması için bilgilendirilmelidir.

- Eğitimcilerin, öykü okuma ve anlatma etkinliklerinde çocukları, karakterlerin zihnini okurken ve empati kurarken yönlendirecek sorularla onlara destek olmaları vurgulanmalıdır.

- Ebeveynlere ve eğitimcilere kitaplardaki resimler hakkında konuşmanın önemli olduğunun, çocukların resimler yoluyla öykü karakterlerinin zihinsel durumlarını ve neler hissettiğine dair pek çok ipucunu gözlemlemelerinin mümkün olabileceğinin anlatılması yarar sağlayacaktır.

- Yayınevlerinin çocuklara yönelik kitap hazırlarken çocuklarla birlikte çalışmaları daha doğru bir yaklaşımla kitap hazırlanmasını sağlayacaktır.

- Bu araştırmada okul öncesi dönem 60-72 aylık çocuklarla çalışılmıştır. Çalışma 3-4 yaş grubu ve ilköğretime devam eden çocuklarla uygulanarak planlanabilir.

- Araştırmada normal gelişim gösteren çocuklalar çalışılmıştır. Çalışma özel gereksinimli çocuklarla yapılarak resimli öykü kitaplarının bu çocukların empati ve zihin okuma becerilerine katkısı araştırılabilir.

- Araştırmada sadece çocuklarla çalışılmıştır. Öğretmen ve ebeveynlerle çalışılarak karşılaştırılmalı çalışmalar yapıllabilir.

\section{KAYNAKÇA}

Alper, T. (2012). Resimli kitaplardaki karakterlerin duygu durumlarmın incelenmesi. (Yayımlanmıs yüksek lisans tezi). Çukurova Üniversitesi, Sosyal Bilimler Enstitüsü, Adana.

Akyol, T. (2012). Resimli çocuk kitaplarnda yer alan dĕgerlerin incelenmesi. (Yayımlanmamış Yüksek Lisans Tezi). Hacettepe Üniversitesi, Sağlık Bilimleri Enstitüsü, Ankara. 
Bilgin, H. (2011). 5-6 yas çocuklarna yönelik 1990-2010 ynllar arasinda basılan resimli kitaplarn çocuğa görelik kavramma göre incelenmesi. (Yüksek lisans tezi). Marmara Üniversitesi, Eğitim Bilimleri Enstitüsü, İstanbul.

Bruhn, M. J. (2011). Introduction: exchange values: poetics and cognitive science. Poetics Today, 32(3), 403-460.

Crane, M.T. (2001). Shakespeare's brain: reading with cognitive theory. Princeton, NJ: Princeton University Pres.

Demircan, C. (2006). TÜBİTAK çocuk kitaplığı dizisindeki kitapların dış yapısal ve iç yapısal olarak incelenmesi. Mersin Üniversitesi Ë̆itim Fakültesi Dergisi, 2(1), 12-27.

Dunbar, R. (2000). "On the origin of the buman mind." In evolution and the buman mind: modularity, language, and the meta-cognition. Cambridge: Cambridge university press.

Erinç, S. (2004). Resmin eleştirisi üzerine. Ankara: Ütopya Yayınları.

Ergenekon Y. (2012). Sosyal yeterlilikle ilişkili kavramlar ve sosyal yeterliliğ̈n bileşenleri. Ankara: Vize Yayıncilik.

Fang, Z. (1996). Illustrations, text, and the child reader: what are pictures in children's storybooks for? Reading Horizons, 37, 130-142.

Gallagher, H. L., Frith, C. D. (2003). Functional imaging of theory of mind. Trends in Cognitive Sciences, 7(2), 77-83.

Ganea, P. (2008). Transfer between picture books and the real world by very young children. Journal of Cognition and Development, 9, 46-66.

Gavins, J., and Steen, G. (Eds.). (2003). Cognitive poetics in practice. London: Routledge.

Gerrig, R. J. (2005). Psychological approaches to narrative. New York: Routledge.

Gönen, M., Katranc1, M., Uygun, M. ve Uçuş, Ş. (2011). İlköğretim birinci kademe öğrencilerine yönelik çocuk kitaplarının, içerik, resimleme ve fiziksel özellikleri açısından incelenmesi. Eğitim ve Bilim, 36(160), 250-265.

Gönen, M., Uludağ, G., Tanrıbuyurdu, E. F. \& Tüfekçi, E. (2014). 0-3 yaş çocuklarına yönelik resimli çocuk kitaplarının özelliklerinin incelenmesi. Hacettepe Üniversitesi Eğitim Fakültesi Dergisi, 29(1), 126-139.

Greenhoot, A. F. \& Semb, P. A. (2008). Do illustrations enhance preschoolers' memories for stories? Age-related change in the Picture facilitation effect. Journal of Experimental Child Psychology, 99, 271-287.

Gürel, P. (2006). Ögrretici bikeyyeler yoluyla düsünce ve duygu eğitimi tanmmlar ve yöntemler. (Yayınlanmamış yüksek lisans tezi). Marmara Üniversitesi, İstanbul.

Hakemulder, J. (2000). The moral laboratory: experiments examining the effects of reading literature on social perception and moral self-concept. Amsterdam and Philadelphia: John Benjamins Publishing Company. 
Herman, D. (2003). Introduction in narrative theory and the cognitive sciences. Stanford: Center for the Smdy of Language and Information.

Hess, C.K., Hatfield, E., \&Chentob, C. (1992). Assessments of the emotional states of others: conscious judgments versus emotional contagion. J SocClin Psych, 11(2), 119-128.

Hess, U. \& Blairy, S. (2001). Facial mimicry and emotional contagion to dynamic emotional facial expressions and their influence on decoding accuracy. International Journal of Psychophysiology, 40(2), 129-141.

Işıtan, S. (2005). Resimli coouk kitaplarmm benlik kavramiyla ilgili konular içermesi yönünden incelenmesi.(Yüksek lisans tezi). Hacettepe Üniversitesi, Sağlık Bilimleri Enstitüsü, Ankara.

Keen, S. (2010). Empaty and the novel. New York: Oxford University Press.

Kiefer, B. (1993). Visual criticism and children's literature. University of Illinois at UrbanaChampaign:USA.

Klemin, D. (1996). The art of art for children's books. New York: Potter

Miller, C.A. (2006). Developmental relationships between language and theory of mind. Am J Speech Lang Pathol, 15(2), 142-54.

Nikolajeva, M. (2012). Reading other people's minds through word and image. Children's Literature in Education, 43, 273-291.

Nikolajeva, M. (2013). Picturebooks and emotional literacy. The Reading Teacher, 67(4), 249-254.

Oğuzkan, A. F. (2000). Cocuk edebiyatı. Ankara: Anı Yayınc1l1k

Oğuzkan, F. (2013). Çocuk edebiyatı. Ankara: Anı Yayıncılık

Özcan, M. (2004). Bilisssel bilim çerçevesinde filmsel anlatı ve görsel algilama. (Yayınlanmış yüksek lisans tezi). Ankara Üniversitesi, Sosyal Bilimler Enstitüsü, Ankara.

Palmer, A.(2005). Intermental thought in the novel: die Middlemarch mind. Style, 39(4), 427-39.

Pantaleo, S. (2005). 'Reading' young children's visual texts. Early Childhood Researcher Practice, 7(1), $1-15$.

Sever, S. ( 2003). Çocuk Kitaplarına Yansıtılan Şiddet (Milli Eğitim Temel Yasası ve Çocuk Haklarına Dair Sözleşme Bağlamında Bir Değerlendirme). Eğitim Bilimleri Fakültesi Dergisi, 35, 1-2.

Schnotz, W. (2002). Towards an integrated view of learning from text and visual displays. Newyork:Educational Psychology Review.

Sever, S., Dilidüzgün, S., Neydim, N., Aslan, C. (2007). İlköğretimde çocuk edebiyatı. Eskişehir: Anadolu Üniversitesi Yayınları.

Siegal, M. \& Varley, R. (2002). Neural systems involved in "theory of mind". Nature Reviews: Neuroscience, 3, 463-471. 
Sipe R., L. (1998). How picture books work: A semiotically framed theory of textpicture relationships. Children's Literature in Education, 29(2), 97-108.

Stockwell, P. (2002). Cognitive poetics: an introduction. London, UK: Routledge.

Strayer, J. (1989). Children's helping strategies: influences of emotion, empathy and age. New directions for child development, 44, 85-105.

Tekin, A. K., \& Tekin, G. (2006). Parents' knowledge level about the picture books they use for children. Hacettepe Üniversitesi Eğitim Fakültesi Dergisi, 31, 159-168.

Temel F., Ersoy Ö., Avcı N. ve Turla A. (2005). Gað̧i erken çocukluk değerlendirme aracı. Ankara: Rekmay Limited Şirket.

Tepecik, A. \& Kayabekir, T. (2017). Resim-metin ilişkisinde yapısal ve bilişsel kavramların tasarım sürecine etkisi. Atatürk Üniversitesi Sosyal Bilimler Enstitüsü Dergisi, 21(4), 1641-1653.

Tokgöz, İ. (2006). Okulöncesi çocuklarna yönelik kitaplarn dil gelisimi ve anlambilimsel açıdan değerlendirilmesi. (Yüksek lisans Tezi). Dokuz Eylül Üniversitesi, Sosyal Bilimler Enstitüsü, İzmir.

Vermeule, B. (2010). Machiavellian narratives, In L. Zunshine (Ed.), Introduction to cognitive culturel studies. (s.214-230), Johns Hopkins University Pres, Baltimore.

Yıldırım, A. \& Şimşek, H. (2016). Sosyal Bilimlerde Nitel Araştırma Yöntemleri. Ankara: Seçkin Yayıncilik.

Wohlgemuth, G.T. (1998). Cildren's literature and its translation. (Unpublished master's thesis). University of Surrey, UK.

Zunshine, L. (2006). Why we read fiction: theory of mind and fiction. Columbus: Ohio State University Press.

Zunshine, L. (2015). The Oxford handbook of cognitive literary studies. London: Oxford University Press. 